\title{
Haugen som gravfelt
}

\author{
BARBRO DAHL
}

Dahl, B. I. 2016: The burial mound as a grave field. AmS-Varia 58, 77-95, Stavanger. ISSN 0332-6306, ISBN 978-82-7760-167-0 Preconceptions about the construction and function of burial mounds can heavily influence the degree of complexity one is apt to see in the field. Rather than seeing a burial mound as the result of a single moment in time, a single burial in prehistory, the mound should be considered as an entire grave field in use over a long period. The excavation of a burial mound at Hålandsmarka, in Time municipality, southwestern Norway, revealed that the monumental structure actually consisted of many different structures and was developed over the course of 2,000 years. By setting aside the standard model of a single burial centrally placed in a homogenous mound, and focusing on the processes of construction and activities that may have left recoverable traces in and around the mound, the excavation allowed for the development of new insights into the longterm use of the site before, during, and after the burials. It is argued that the situation at Hålandsmarka is not unique, and that the ability to accurately document such complexities in grave mounds is heavily dependent upon excavation strategy. It is further argued that the responsibility to document these processes must be taken into consideration in the planning of future excavations.

Barbro Dahl, Museum of Archaeology, University of Stavanger, NO-4036 Stavanger, Norway. Phone: (+47) 47383422. E-mail: barbro.dahl@uis.no

Keywords: burials, monuments and memory, long-term use, construction and deconstruction, Bronze Age and Iron Age.

"Sekundære begravelser i eldre hauger er langt vanligere gravform enn reising av ny haug" (Møllerop 1953b:56).

\section{Gravhauger i forsking og forvaltning}

Muligheter for å kartlegge gravminners kompleksitet kan ses i sammenheng med utgravings- og dokumentasjonsstrategi. Men som et første premiss vil vårt syn på gravminner virke styrende for hvilken grad av kompleksitet det vil være mulig å åpne opp for. Framfor å betrakte gravminner som spor etter én begravelse på ett bestemt tidspunkt, bør det tas høyde for at hauger kan ha fungert nærmest som gravfelt i bruk gjennom et langt tidsrom. Utgravinga i Hålandsmarka i Time kommune i 2008 (Frydenberg 2009, Gil 2009, Thingnæs 2009) illustrerer hvordan én enkel gravhaug kan romme ny kunnskap om gravskikk gjennom mer enn to millennia. Et bredt utvalg av eksempler fra eldre utgravinger, først og fremst fra Rogaland, viser at haugen i Hålandsmarka ikke er å oppfatte som et isolert tilfelle (Fig. 1).

De fleste undersøkelser av monumentale hauger er av gammel dato, noe som kan forstås på bakgrunn av at vernet av store hauger i det lengste blir forsøkt opprettholdt i norsk kulturminneforvaltning. Da både det teoretiske og det metodiske rammeverket har gjennomgått store endringer, ville dette stille oss overfor nye muligheter og utfordringer i tilnærminga til haugen i Hålandsmarka. Ved planlegging av prosjektet ble det fokusert på en utgravingsmetodikk som kunne fange opp og dokumentere konstruksjonsfaser. Ved å dekonstruere monumentet i ulike handlinger innenfor stratigrafiske sekvenser var det ønske om økt innsikt i ulike forhistoriske praksiser og religiøse forestillinger (jf. Gansum 2004, Gansum \& Østigård 2004:69).

I beitemarka hvor det var planlagt industriutbygging på Håland, var det registrert fire synlige gravminner, i tillegg til 20 rydningsrøyser, to gardfar og ei innhegning.

Områdene rundt de synlige gravminnene ble sterkt vektlagt da de har et høyt potensial for innsikt i aktiviteter som kan ha funnet sted før, under og etter begravelser (Dahl et al. 2008). Således var det nødvendig å legge opp til en omfattende avdekking av undergrunnen rundt de kjente kulturminnene for om mulig å kunne oppnå økt kunnskap om aktiviteter uten bevarte, synlige spor på overflata. Ved avdekking rundt to rikholdige vikingtidsgraver anlagt ved og over to graver fra yngre romertid ble det funnet ei ny røys med ei rik skjelettgrav fra eldre vikingtid sør på feltet (Fig. 2). Samtidig viste det seg at undergrunnen rundt den monumentale haugen øst på 


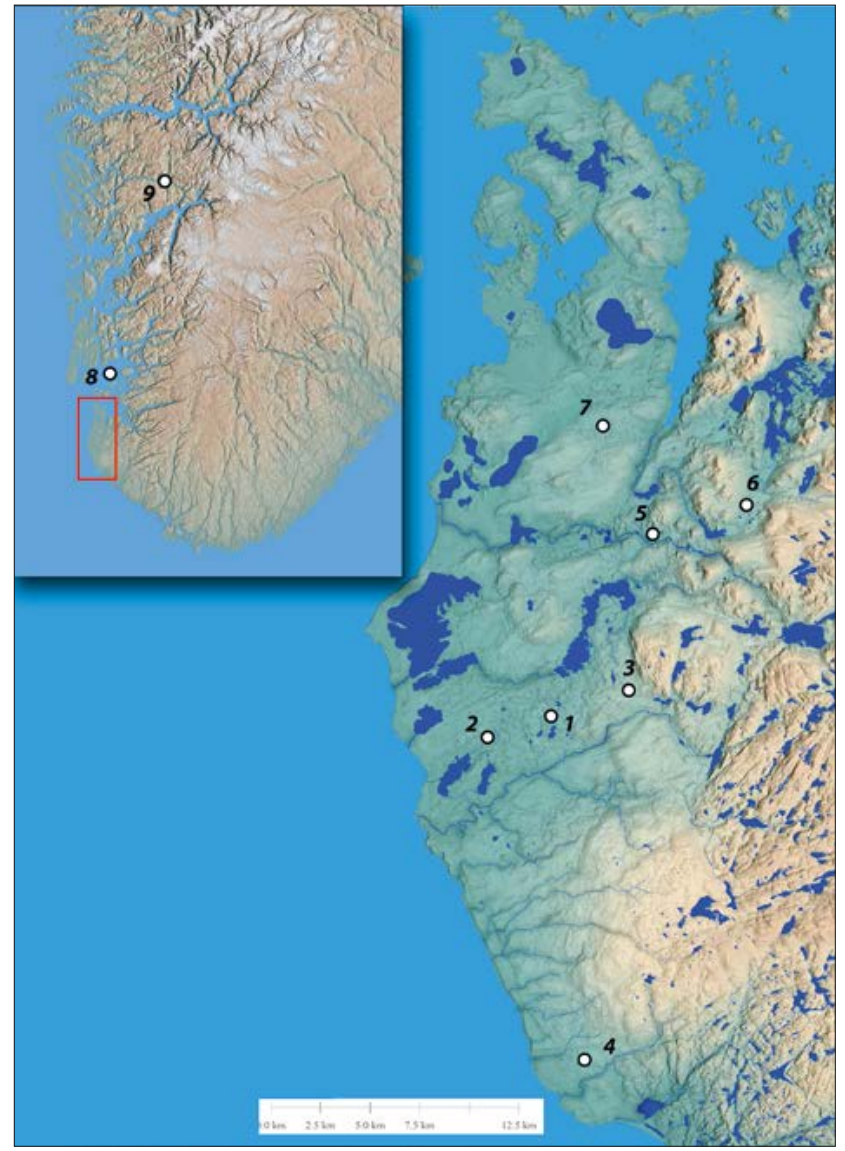

Fig. I. Lokalisering av Hålandsmarka i forhold til andre hauger med mange faser (jf. Tabell I). I) Hålandsmarka, Time 2) Salte, Klepp 3) Lye, Time 4) Vigrestad, Hå 5) Foss-Eikeland, Sandnes 6) Medhaug, Sandnes 7) Ormshaug, Sandnes 8) Helgøy, Finnøy 9) Sakrishaugen, Voss. Kartet over Jæren er basert på et kart fra 1855 før uttapping av vannene. III: Theo Gil.

Fig. I. Location of Hålandsmarka related to other mounds with several phases (see Table I). I) Hålandsmarka, Time 2) Salte, Klepp 3) Lye, Time 4) Vigrestad, Ha 5) Foss-Eikeland, Sandnes 6) Medhaug, Sandnes 7) Ormshaug, Sandnes 8) Helgøy, Finnøy 9) Sakrishaugen, Voss. The map of Jæren is based on a map from 1855 with the drained lakes indicated. III: Theo Gil.

høydedraget var preget av en stor tetthet av anlegg som ikke var synlige på overflata. Det ble åpnet for et langt tidsperspektiv som ikke bare fokuserte på datering av begravelse, men som viet oppmerksomhet til byggeprosesser og hendelser som kan ha avsatt varige spor i og rundt anlegget. Utgravingsdokumentasjonen ble organisert i en matrise for å skape oversikt over lag, faser, forstyrrelser, strukturer, funn og prøver i det komplekse anlegget (Fig. 3).

I følgende presentasjon vil fokus rettes mot de mange anleggene relatert til den monumentale gravhaugen øst på høydedraget. Haugen, som var 21 meter i diameter og 2,2 meter høy, viste seg å romme ei rekke suksessive anlegg fra bronsealder periode I til overgangen mellom folkevandringstid og merovingertid. Det eldste identifiserte anlegget øst på høydedraget er en tilnærmet rektangulær haug konstruert i eldre bronsealder. Haugen var omgitt av et kantkjede og to anlegg tolket som graver var anlagt ut fra kantkjedet. Videre lå flere anlegg som satellitter rundt den rektangulære haugen. I førromersk jernalder bygges ei steinlegging over vestlig del av den rektangulære haugen. Før konstruksjonen av det nye anlegget er det tydelig at det har foregått en utjevning av de eldre anleggene på stedet. I eldre romertid blir steinlegginga gjenbrukt ved innplassering av en kremasjonsbegravelse. Både steinlegging og store deler av den rektangulære haugen var dekket av et kullag som viser til omfattende aktivitet på stedet i yngre romertid. I samme periode konstrueres det ei røys over det tykke kullaget. De mange anleggene krones av et sirlig konstruert byggverk av sorterte steinlag. Et stort kammer med gjentatte begravelser gjennom hele folkevandringstid bygges inn i røysa, og ei jordkappe forsegler alle eldre anlegg på stedet.

Før presentasjonen av de mange ulike anleggene kan det være nødvendig med en kort redegjørelse for anvendte begrep. Hva angår skillet mellom haug og røys, er det en innarbeidet forståelse av at røyser er bygd opp utelukkende av stein, mens hauger består av jord eller en kombinasjon av stein og løsmasser (jf. Løken 1974:58, Wangen 1998:5, Dommasnes 2001:23, Gansum 2004:106, Østmo \& Hedeager 2005:136). Kjernerøys betegner ei kjerne av stein uten innblanding av jord, anlagt på haugbunnen og dekket av ett eller flere lag løsmasse (Næss 1996:12). Steinlegging vil bli benyttet om sammenhengende steinpakning eller brolegging av ett til to lag stein, iblandet fyllmasser av jord eller grus. Overflata er plan og formen kan variere fra rund til rektangulær eller trekantet (Løken 1974:59, Wangen 1998:5, Dommasnes 2001:24). Det kan videre være nødvendig å avklare begreper som blir benyttet for å beskrive detaljkarakteristika ved anleggene på Håland. I følge Trond Løken (Løken 1974:55) kan kantstein brukes i betydningen lang stein som hviler på sin minste tverrsnittflate og som er intensjonelt plassert $i$ et anleggs periferi. Kantmarkering kan bestå av enkeltliggende kantstein eller andre steiner som markerer anleggets ytterkant og som skiller seg ut fra øvrige stein i anlegget med hensyn til størrelse, form eller plassering. Kantmarkeringa kan være lagt som et tettliggende kjede av stein rundt anlegget og omtales da som kantkjede. Kantkjedet kan være dobbelt eller bestå av flere lag stein. Steinene i kantkjedet er gjerne jevnstore, men steinene kan også være av ulik størrelse (Wangen 1998:6).

Jenny-Rita Næss har fremmet en inkluderende definisjon av gravbegrepet som fokuserer på den fortidige handlingen:

«Grav - betegnelse på et sted hvor den døde, eller restene av den døde, legges ned» (Næss 1996:12). 


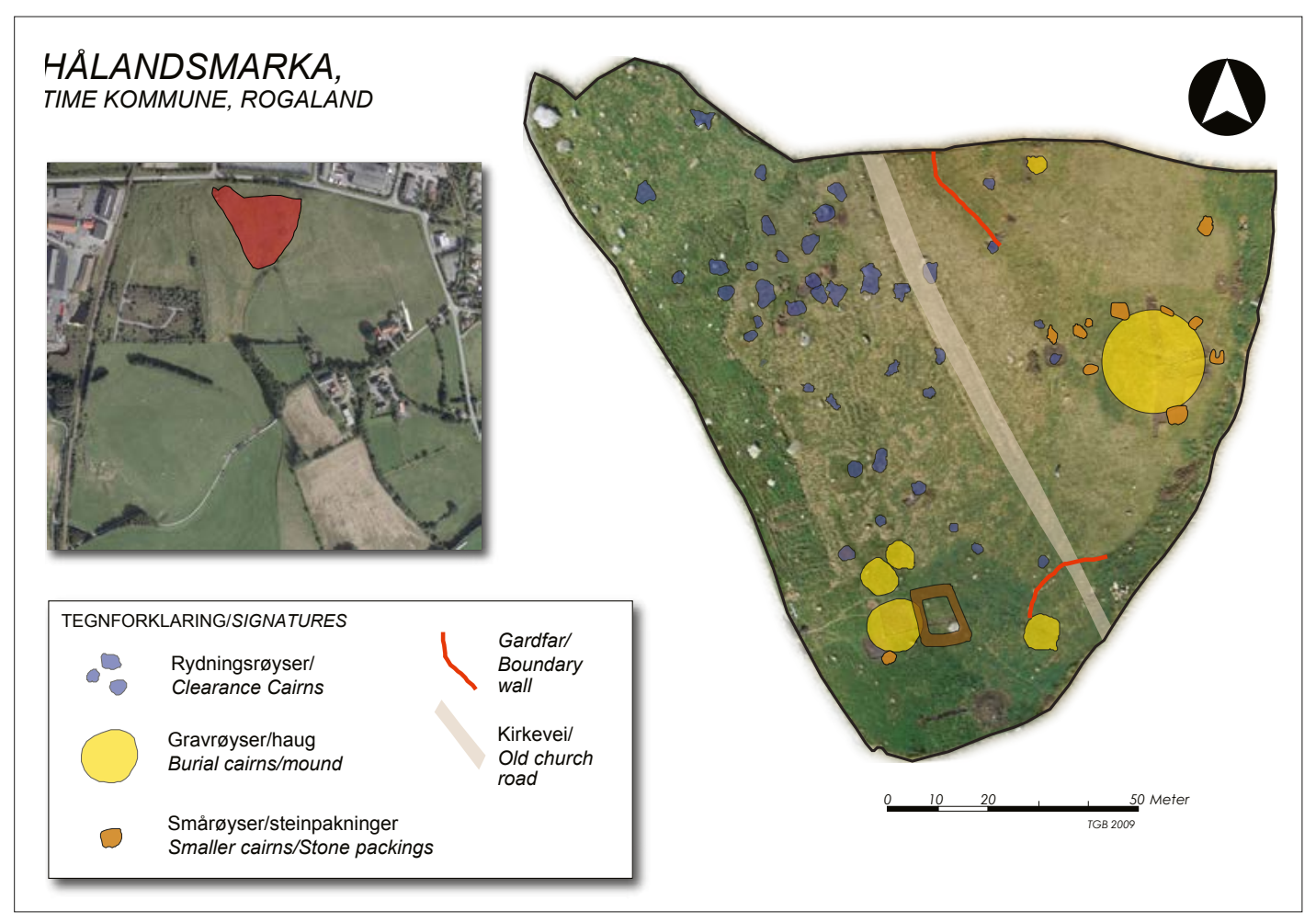

Fig. 2. Lokaliteten Hålandsmarka.

Til venstre ses landskapet rundt utgravingsfeltet. III. Theo Gil.

Fig. 2. The site Hålandsmarka. To the left the landscape around the excavation site can be seen. III. Theo Gil.

Gravbegrepet til Næss kan suppleres med Trond Løkens definisjon av gravformen skjelettgrav:

«Skjelettgrav, haugbunn er brukt i betydningen begravelse med ubrent lik som er plassert på det naturlige terrengnivå. Bestemmelse som skjelettgrav er gjort avhengig enten av funn av skjelett(deler), av at nedgravningen er tilstrekkelig stor for et menneske og/eller at oldsakene ligger på en slik måte at de vitner om en plassering i relasjon til et lik. De må da ikke vise tegn til ildbeskadigelse (deformering, glødeskall) eller ligge i et kullag» (Løken 1974:56).

Når det gjelder gravtyper med brente bein, eksisterer det ei rekke termer. Vivian Wangen presenterer i sin magistergrad en fyldig oversikt hvor hun setter et hovedskille mellom urensete, brente bein kontra rensete, brente bein (Wangen 1998:7). Termene ble fors økt benyttet ved analysering av prosjektets begrensete beinmateriale, men forsøk på innplassering i systemet ble opplevd som lite oppklarende for vår del. Den svært finmaskete oversikten over ulike typer kremasjonsgraver vurderes som mer anvendelig i tilfeller med et større, mer velbevart gravmateriale.

\section{Konstruksjon av rektangulær haug i bronsealder periode I}

Ved undersøkelse av gravanlegg blir det forholdsvis ofte påtruffet spor etter eldre aktiviteter under anleggene (Petersen 1924, Myhre 1965, Næss 1969, Magnus Myhre 1968, Haraldsen 1978, Randers 1988, Hemdorff 1989). Under haugen i Hålandsmarka ble det både funnet kraftig slitte leirkarskår og to kullholdige nedgravinger datert til mellommesolittikum, BC 7270-7045 og BC 6750-6600 (TUa-8128, TUa-8321). Strukturene ses i relasjon til de spredte flintartefaktene funnet ved avdekkinga av hele høydedraget der en littisk funnkonsentrasjon lengst sør peker seg spesielt ut (S12454). De slitte leirkarskårene indikerer omfattende aktiviteter som har ei nedre tidsgrense i eldste bronsealder ved bygging av en rektangulær haug.

Den tilnærmet rektangulære haugen hadde et kantkjede som besto av flate, større steiner anlagt med langsida ut (Fig. 4). Anlegget var 12 meter langt med bredde fra 4,0 til 5,5 meter. Like sør for midtaksen ble det påvist tre ansamlinger av kantstilte heller anlagt direkte oppå undergrunnen. Det ble ikke funnet bevarte spor etter begravelse, og de mulige gravgjemmene framsto som kraftig forstyrrete. Hele anlegget hadde vært gjenstand for omfattende utplanering, og fyllmassen ble ikke vurdert som et godt grunnlag for sikker datering. Da en av steinene i kantkjedet ble løftet opp, ble det avdekket kull som har gitt en bakre tidfesting av anlegget til BC 1930-1785 (TUa-8127). Samtidig har trekull fra ei kraftig brenning som tydelig må ha foregått etter at kantkjedet var etablert, gitt datering til BC 1500-1410 (TUa-8126). Den nedre grensa for tidfesting av haugen underbygges av to sekundære anleggs suksessive dateringer til BC 1425-1395 og BC 1390-1265 (TUa-8323, TUa-8322). Den rektangulære haugen kan således tidfestes innenfor perioden BC 1930-1410. Det holdes som mest sannsynlig 


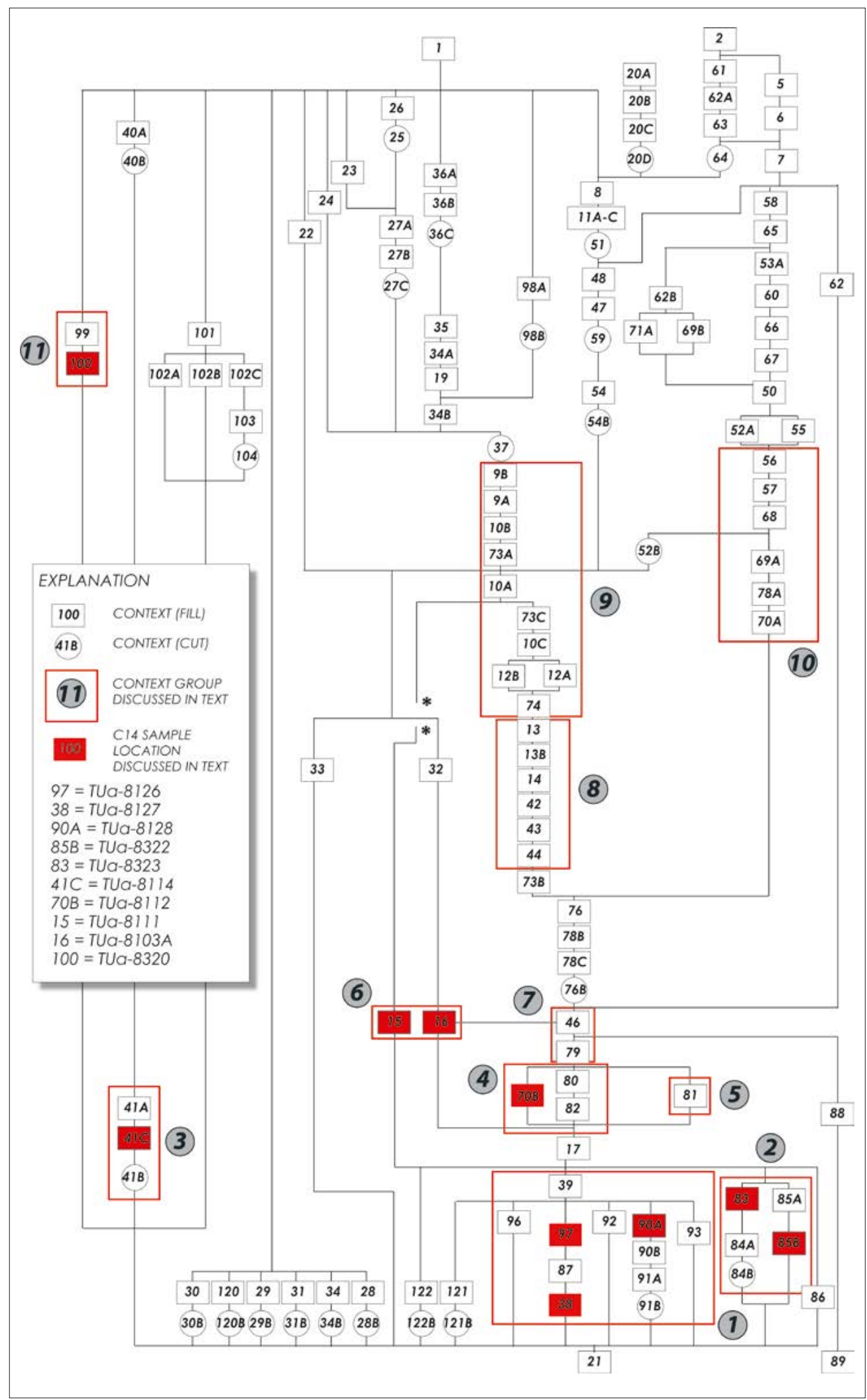

Fig. 3. Haugens matrise. Kontekster er forstått som "an individual archaeological unit of stratification which represents a specific processual event or events in time" (McLees et al. 1994:13). Kontekstene har blitt skilt ut og nummerert som fill, cut eller interface (Harris 1979, Brown III \& Harris 1993). Under etterarbeidet har noen av enhetene blitt videre inndelt $\mathrm{i}$ undergrupper omtalt med store bokstaver (jf. 29A, 29B). I matrisen er kontekstene fill og interface markert som rektangulære bokser, mens cut har sirkulær markering. Mellom kontekstene løper det relasjonslinjer, fra yngst øverst til eldst i bunnen.

Kontekstgrupper har blitt tolket og arrangert som ulike sekvenser i bygginga av det sammensatte monumentet, markert med grå numre som korresponderer med Fig. 6 . III.: Theo Gil.

Fig. 3. The matrix of the mound. We have considered as contexts "an individual archaeological unit of stratification which represents a specific processual event or events in time" (McLees et al. 1994:/3).

The contexts have been numbered and classified as fill, cut or interface (Harris 1979, Brown III \& Harris 1993).

During the after work, some of the units have been split into subgroups marked by capital letters (like 29A, 29B). In the matrix, the contexts fill and interface are marked as rectangular boxes, while cut is marked by a circle. The relation between the contexts is marked by a connection line (route), running from the later on top to the oldest below. Context groups have been interpreted and arranged as sequences in the construction of the complex monument, marked by grey numbers corresponding to Fig. 6. III.: Theo Gil.

at anlegget kan plasseres innenfor yngste del av tidsrommet ettersom den kraftige brenninga framstår som foretatt direkte oppå undergrunnen inntil kantkjedet. Manglende mellomliggende torvlinser gir et inntrykk av kort tidsspenn mellom haugens anleggelse og brenninga.

\section{Paralleller til den rektangulære haugen}

Under ei røys på Helgøy i Finnøy kommune ble det funnet et eldre anlegg i form av to parallelle steinrekker tolket som kantkjede til ei langrøys (Barclay 1984). Anlegget smalnet i likhet med haugen i Hålandsmarka 


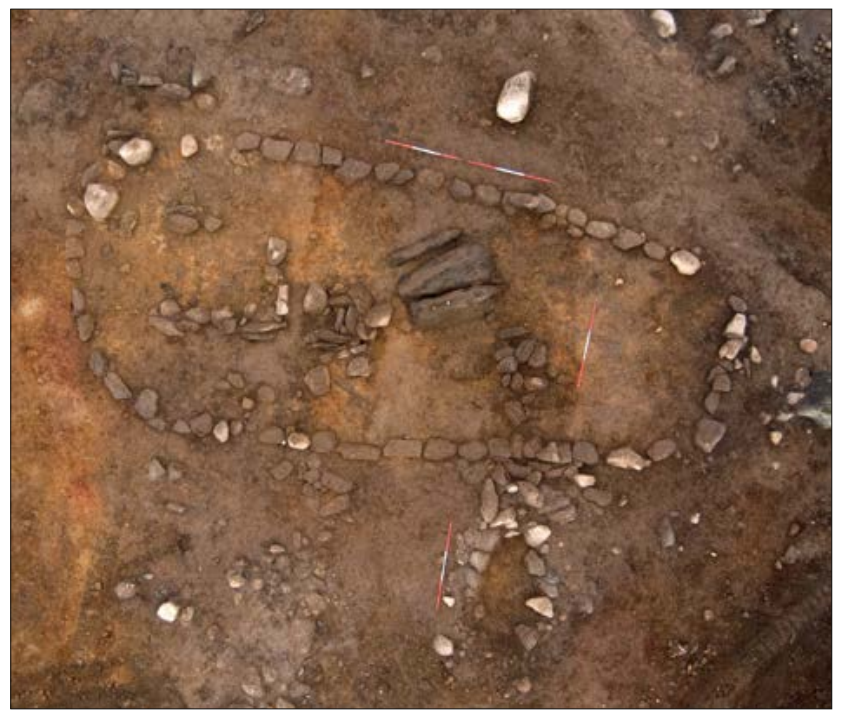

Fig. 4. Den rektangulære haugen i Hålandsmarka. Foto: Birdy Photographs.

Fig. 4. The rectangular mound in Hålandsmarka. Photo: Birdy Photographs.

inn mot den ene enden. Situasjonen minner for øvrig om en av konstruksjonsfasene i ei røys på Nordbø i Rennesøy kommune der et langovalt steinkjede også tydelig smalnet inn mot den ene enden (Høgestøl 1995:223-224). Vi har imidlertid flere opplysninger om anlegget på Helgøy siden det der ble påvist et kammer orientert langs anleggets lengderetning (B på Fig. 5). Dekkhellene vest i kammeret var sammenraste og gravgjemmet framstår som plyndret. Utenfor østlig ende av kammeret ble det funnet en liten konsentrasjon av brente bein tolket som indikasjon på ytterligere ei grav. Utenfor det rektangulære anlegget, men innenfor den yngre, sirkulære røysa ble det identifisert to graver (A og C på Fig. 5). I et lite, hellebygd gravgjemme ble det funnet brente bein og en ring av bronse. Nær overflata ble det funnet brente bein og skår fra et kar tidfestet til yngre bronsealder (Barclay 1984:3). Således holdes det som sannsynlig at den underliggende langrøysa kan tidfestes tilbake til eldre bronsealder. Ut fra kantkjede, anleggets form, det tomme gravgjemmet og antatt alder kan anlegget på Helgøy betraktes som nærmeste parallell til den rektangulære haugen i Hålandsmarka.

Det rektangulære anlegget på Håland har også likheter med en annen anleggskategori. De skandinaviske kulthusene har avstedkommet en interessant diskusjon hva angår definisjon, bruk og datering (Anglert et al. 2006). Problemstillingene betraktes i høy grad som relevante $i$ en diskusjon av det langstrakte, funntomme anlegget fra bronsealder i Hålandsmarka. Helena Victor (2006) definerer kulthus som en huslignende konstruksjon som antas å ha inngått i en sakral sammenheng. Anleggene er gjerne funntomme eller inneholder få funn i gulvflata, så som små leirkarbiter, bein og flint, noe som har gjort tidfesting vanskelig. Anleggskategorien med veggvoller av stein- og jordmasser tidfestes gjerne indirekte ut fra nærliggende graver, samt likhet med andre kulthus som nettopp er tidfestet på tilsvarende indirekte måte.

Ut fra nyere undersøkelser stiller Fredrik Svanberg (Svanberg 2006:124) seg kritisk til tidligere tolkinger av kulthus. I følge Svanberg har tolking av kulthus vært preget av det han karakteriserer som mystifisering, gjerne sentrert rundt overgangsriter. I stedet for å betrakte anleggene som noe som kompletterer andre graver, bør kulturminnene betraktes som graver i seg selv. Ved moderne metoder har det lykkes å påvise graver i anleggene og således kan begrepet husgraver sies å være mer dekkende enn kulthus. Anleggene kan, som andre graver, fortsatt ha blitt benyttet som steder for dødsritualer og gravkult. Svanberg trekker paralleller til europeiske longbeds fra yngre bronsealder. Gravkategorien kan i likhet med de skandinaviske anleggene tolkes som symbolske hus, som et ønske om å understreke en sterk kopling mellom familiens bosted og gravsted.

Tolkinga gir interessante innfallsvinkler for forståelsen av det langstrakte anlegget i Hålandsmarka, og hvorfor det ble valgt en svært avvikende form i forhold til de store, runde jordhaugene som preger jærlandskapet i eldre bronsealder. Haugen har svært avrundede hjørner

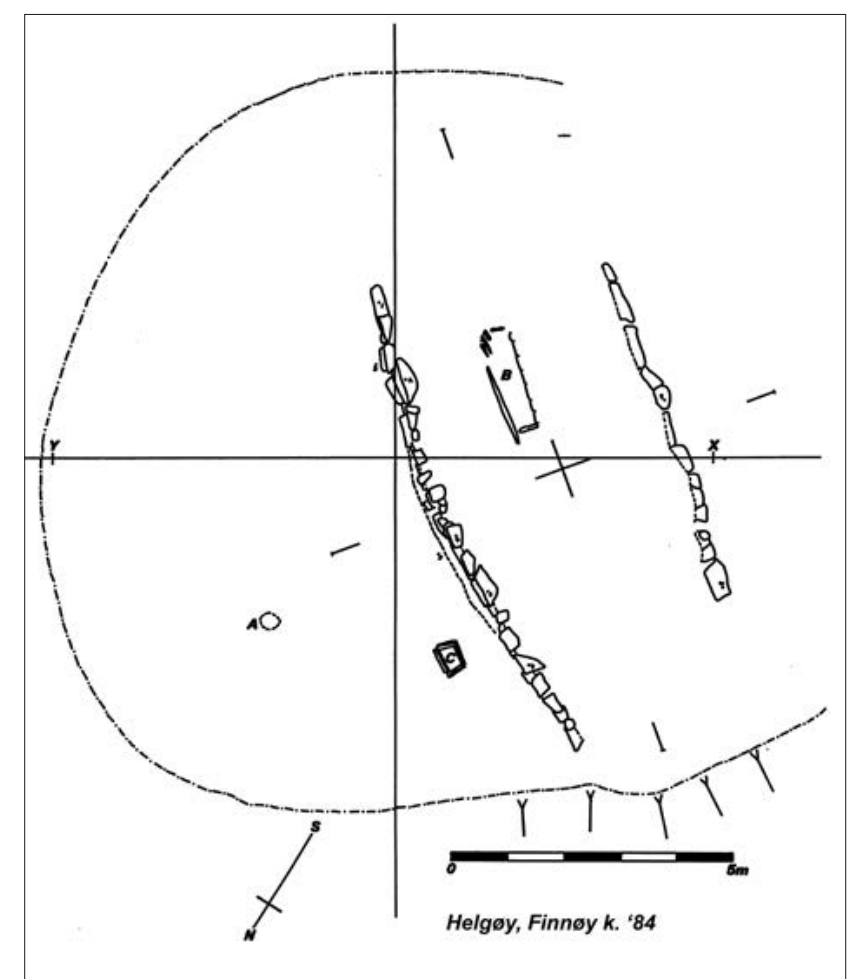

Fig. 5. Det rektangulære anlegget på Helgøy, Finnøy kommune, Rogaland (Barclay 1984).

Fig. 5. The rectangular structure at Helgøy, Finnøy municipality, Rogaland (Barclay 1984). 
som muligens kan ses i lys av langhusenes avrundede gavler i eldre bronsealder. Gravene ble ikke nødvendigvis anlagt i umiddelbar nærhet til bosettinga i eldre bronsealder. En synlig plassering i landskapet var viktig ved valg av gravsted, mens en mer skjermet beliggenhet ser ut til å ha vært foretrukket ved lokalisering av bygninger (jf. Dahl 2014). Ved undersøkelser av hus fra bronsealder i Rogaland påvises det ikke samtidige graver. Mangel på samlokalisering av bygninger og graver kan kanskje nettopp være en årsak til at gravanlegg bygges med samme form som hus. Det er også mulig at form ble valgt ut fra hva som var mest anvendelig ved videre bruk av anlegget. Framfor en ruvende jordhaug ble det heller valgt å konstruere et lavt, langstrakt anlegg som kunne benyttes som en scene og fokalpunkt for videre ritualer. Videre bruk og omfattende aktiviteter gjennom hele bronsealder framstår som et sentralt punkt ved de langstrakte anleggene, både i Sverige og i Hålandsmarka.

\section{Satellittanlegg fra eldre og yngre bronsealder}

Langs kantkjedet til den rektangulære haugen ble det avdekket to anlegg tolket som mulige graver. Begge anleggene hadde kantstilte heller langs kanten og forekomst av flate steiner i toppen, men var preget av den samme utplaneringa som den rektangulære haugen. I likhet med restene etter kamre innenfor den rektangulære haugen ble det imidlertid ikke funnet bevarte spor etter begravelse. Fosfatanalysene ga svakt forhøyde verdier som kan sies å styrke antagelsen om skjelettbegravelser i de to anleggene (Amundsen 2008). De to anleggene har gitt dateringer til BC 1425-1395 og 1390-1265 (TUa-8323, TUa-8322). Det er trekull fra fyllmassen i anleggene som er datert, og det er viktig å påpeke usikkerheten ved i hvilken grad det daterte trekullet kan relateres til de antatte skjelettbegravelsene. På den andre sida vil anleggene uavhengig av dateringene kunne plasseres inn i en stratigrafisk kronologi mellom eldre bronsealder periode I og eldre førromersk jernalder da de var dekket av massene fra utplaneringa av den rektangulære haugen.

Mens disse to satellittanleggene var bygd ut fra kantkjedet i den rektangulære haugen, lå det ei røys bygd opp rundt to jordfaste steiner like øst for haugen. I midten av røysa var det en avlang forsenkning tolket som et mulig sammenrast kammer. Det ble ikke funnet bevarte spor etter begravelse, men fosfatprøvene ga klare utslag under anleggets sentrum. Trekull fra anlegget har blitt datert til BC 800-770 (TUa-8114), men her må den samme forsiktighet utøves med tanke på kullets usikre relasjon til eventuell skjelettbegravelse. Vest for haugen ble det undersøkt 17 stolpehull, to av dem datert til yngre bronsealder (TUa-8120, TUa-8121). Det ble ikke identifisert grindbygde huskonstruksjoner, men det er mulig at stolpehullene utgjør spor etter mindre bygninger eller representerer ukjente former for reisverk relatert til bruken av gravstedet i yngre bronsealder.

De ulike satellittanleggene understreker viktigheten av å undersøke området rundt synlige gravanlegg. Felles for anleggene med dateringer til bronsealder er mangel på bevarte spor etter liket. Skjelettbegravelser var framherskende i eldre bronsealder, og det holdes som sannsynlig at det vil være vanskelig å finne bevarte ubrente bein av så høy alder i et surt jordsmonn. Hvis den siste røysa knytta til de to store steinene også skal tolkes som spor etter en begravelse, må vi imidlertid se for oss at skikken med ubrente begravelser kan ha strukket seg helt opp i yngre bronsealder på Håland. Videre kan vi tegne et bilde av den rektangulære haugen som et sentralsted for gravkult gjennom hele bronsealderen. Først i førromersk jernalder kommer det et behov for å ombygge gravmonument på en måte som tar opp i seg de eldre anleggene, og som bygges på samme sted (Fig. 6).

\section{Konstruksjon av steinlegging i førromersk jernalder}

I eldre førromersk jernalder ble det anlagt ei sirkulær steinlegging med et kantkjede over den vestlige delen av den rektangulære haugen (Fig. 7). Steinlegginga tilknyttes bevisst eldre anlegg og understreker at stedet fortsatt spilte en viktig rolle i lokal gravskikk. Steinlegginga fra førromersk jernalder betraktes som en videreføring av eksisterende praksis ved at det bygges et lavt anlegg innenfor et kantkjede. Samtidig kan steinlegginga tas som et uttrykt behov for å tilføre stedet en ny og annerledes ramme for nye begravelser og ritualer. Anleggelsen av steinlegginga i førromersk jernalder kan indikere endrede religiøse forestillinger, endrede ritualer eller endrede forhold til de gravlagte på stedet.

Det kan være vanskelig å gjenfinne spor etter begravelser i førromersk jernalder (jf. Farbregd 1980), og således var identifiseringa av steinlegginga mellom de mange konstruksjonene i Hålandsmarka viktig. Med en gravskikk preget av lave anlegg og manglende overflatemarkering kan vi se for oss at det vil være større muligheter for å påtreffe graver fra perioden ved avdekkinger av gravfelt og rundt synlige kulturminner. Steinlegginger er da nettopp kjent å forekomme samlet i felt (Skjelsvik 1953). I Hålandsmarka ble det imidlertid ikke påvist andre gravanlegg fra førromersk jernalder. I de tilfellene det blir påvist begravelse i de runde steinleggingene, består disse utelukkende av brannbegravelser med få eller ingen gjenstander (Skjelsvik 1953:176, Solberg 
2000:41, Wangen 2009). Den enkle branngrava som ble påvist i steinlegginga i Hålandsmarka kan dermed sies å være karakteristisk for førromersk jernalder. Brannlaget tolket som steinleggingas primærgrav var opptil $10 \mathrm{~cm}$ tykt og sentrert innenfor steinsirkelen. Konteksten har gitt datering til BC 360-195 (TUa-8112). I kullaget ble det funnet svært fragmenterte bein, to slaggbiter, to ubestembare jernfragment og en bit harpiks. Videre ble det funnet 128 leirkarskår av grovmagra gods. Leirkarskårene framsto som sekundært brente, noe som antyder at de har inngått i selve kremeringsprosessen. Det er tydelig at et rikt gravgods ikke ble tillagt en vesentlig rolle verken i forhold til det dennesidige eller det hinsidige i førromersk jernalder. Videre ble det ikke lagt vekt på å bygge gravanlegg som ruvet i landskapet. I den lokale gravskikken må det likevel understrekes at arbeidet med å bygge et varig anlegg må ha vært tillagt betydning, noe som står i kontrast til praksisen med å innplassere nye begravelser i eksisterende anlegg i kommende perioder i Hålandsmarka.

\section{Gjenbruk av steinlegginga i eldre romertid}

I eldre romertid ble et nytt individ begravd i steinlegginga. I sørøstlig del av anlegget ble det funnet en konsentrasjon av brente menneskebein. Sammen med

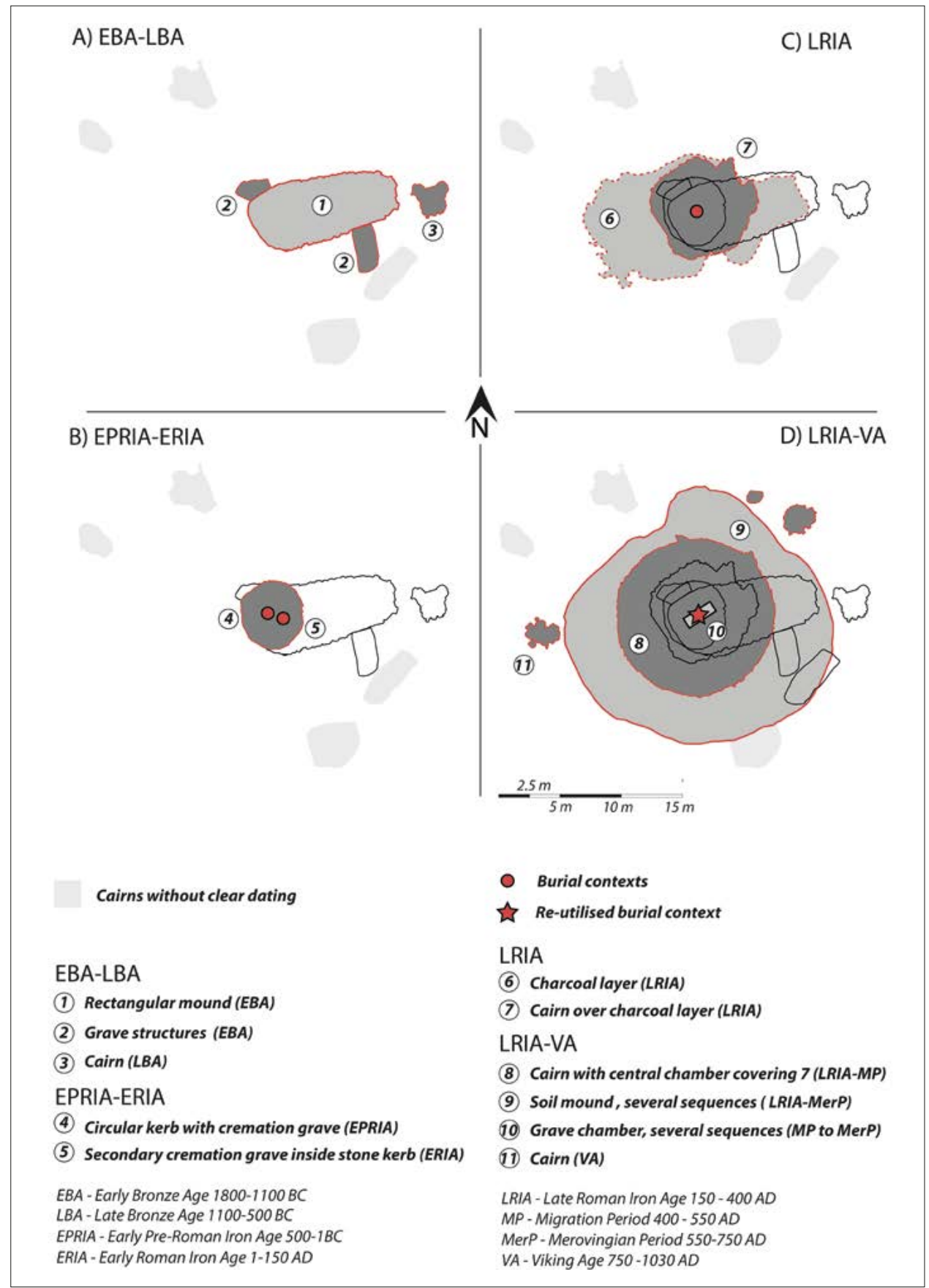

Fig. 6. Plansje over fasene i haugen i Hålandsmarka. III.: Theo Gil.

Fig. 6. The different phases of construction in the mound in Hålandsmarka. III.: Theo Gil. 
beina lå en del av en bronsefibula med tett tvinnet spiral som kan tidfeste begravelsen til slutten av eldre romertid (Almgren 1897). Slike små bøylespenner av bronse dominerer gravfunnene i Rogaland i denne perioden (Møllerop 1953b:57). Fiblene blir gjerne gjenfunnet mer eller mindre fragmentariske, noe som kan ses i relasjon til den store hyppigheten av brannflak.

Mens det ved gravlegging i førromersk jernalder ble bygd et nytt anlegg over den rektangulære haugen fra eldre bronsealder, ble grava i eldre romertid lagt ned i den eksisterende steinlegginga. For det første kan vi anta at det var et spesielt utvalgt individ som fikk æren av å gravlegges sammen med en nå fjern og trolig mytisk person i steinlegginga. For det andre gir begravelsen en klar indikasjon på at det eksisterende anlegget fortsatt spilte en viktig rolle i lokal bevissthet. Mer generelt var steinlegginger fortsatt en vanlig anleggsform for begravelser i eldre romertid (Wangen 1999), og steinlegginger ble også benyttet i den lokale gravskikken i Hålandsmarka gjennom hele romertid. For det tredje kan valget om å gravlegge i et eksisterende anlegg gi indikasjoner på at handlingene knyttet til selve byggeprosessen ikke fylte en sentral rolle i gravritualene i eldre romertid på Håland.

\section{Omfattende kullag fra yngre romertid}

Rundt steinlegginga ble det påvist et omfattende kullag med utstrekning på $120 \mathrm{~m}^{2}$ og tykkelse på opptil $15 \mathrm{~cm}$. To dateringer fra kullagets ulike ender ga sammenfall til AD 260-330 (TUa-8111, TUa-8103A). Det er grunn til å anta at konteksten relativt raskt ble forseglet av nye monumenter, ellers må vi kunne gå ut fra at det svært finkorna kullaget ville blitt utvasket eller trampet utover. Således kan både det omfattende kullaget i seg selv, og det faktum at det ble funnet forseglet av ei rekke konstruksjoner, sies å underbygge inntrykket av et høyt aktivitetsnivå på stedet i yngre romertid. Kullaget kan tas som et tydelig indisium på de ritualer som antas å ha funnet sted både i tilknytning til eksisterende monumenter og i forbindelse med bygging av nye anlegg.

I følge Terje Gansum og Terje Østigård (2004) kan en tilnærming til hauger som ritualer likeledes sies å underbygges av det omfattende kullaget dokumentert mellom kjernerøys og jordkappe i den sørøstlige gravhaugen på Haugar i Tønsberg. Mens liknende kullag påvist under andre gravhauger gjerne tolkes som spor etter kremasjon, deriblant kullaget under Medhaug i Sandnes og Bondehaugen, Kvam i Hordaland (Møllerop 1965, Kristoffersen \& Østigård 2008), argumenteres det for at kullaget i Haugar ikke representerer en vanlig kremasjon. Ut fra trekullets grove karakter og mangel på aske holdes det som sannsynlig at brenninga har foregått $i$ groper eller ovner under lav temperatur, muligens innenfor ulike mindre grupper. Gansum og Østigård mener at kullet så er blitt transportert og deponert i haugen, slik at det ble skapt en stor plattform for utføring av ritualer. Brenning, transportering og deponering kan samtidig ha vært viktige mål i seg selv som kollektiv konstruksjon av monumentet.

Det sotete kullaget under haugen på Håland framstår som et resultat av brenning under høy temperatur, trolig tilført fra andre steder siden det oppsiktsvekkende nok kun ble avdekket ei kokegrop på hele høydedraget. Omfanget kan tas som en indikasjon på at mange mennesker har vært involvert i handlingene. Samtidig som mengde tilført treverk peker mot et klart kollektivt aspekt, kan det ikke utelukkes at den videre prosessen ble kontrollert og orkestrert av en snevrere krets. Det er grunn til å anta at planlegging og regissering lå hos nøye utvalgte individer med spesielle kunnskaper og roller. Ritualene kan betraktes som viktige anledninger både for mobilisering og samhandling, samtidig som vi vil kunne forvente at de utgjorde viktige arenaer og argumenter for eksisterende og kommende maktfordeling. Videre kan det foreslås at ulike komponenter kan ha inngått i brenninga, bestanddeler som tilførte handlingene ekstra effekt samtidig som de kan ha blitt betraktet som spesielle i kraft av deres relasjon til ildprosessen. Det er mulig at kvarts spredt ut over røysa som ble reist over kullaget, kan ha hatt betydning gjennom bruken og relasjonen til den omfattende brenninga og prepareringa av grunnen under anlegget.

\section{Konstruksjon av røys i yngre romertid}

Oppå kullaget datert til yngre romertid, sentrert over steinlegginga fra førromersk jernalder, ble det i yngre romertid reist ei sirkulær røys med en bevart diameter på 9 meter. Anlegget har blitt omtalt som mellomrøysa, da den tydelig skilte seg ut fra de sirlig sorterte lagene av runde steiner i kjernerøysa over. Røysa var bygd opp av store, kantete steiner med et toppdekke av små, runde steiner. Begge steinlagene var preget av en ujevn avgrensing, noe som kan skyldes at deler av anlegget har blitt fjernet i forbindelse med konstruksjon av den yngre kjernerøysas yttermarkering (Fig. 8). Antagelsen underbygges ved at kullaget ble funnet bevart utenfor mellomrøysa, forseglet av den større kjernerøysa. Som nevnt må vi anta at kullaget er bevart av den grunn at det hurtig ble forseglet av mellomrøysa.

Det var noe vanskelig å definere sikre graver tilhørende anlegget ettersom et kammer ble anlagt oppå de eldre begravelsene i folkevandringstid. Det holdes som sannsynlig at det sammenblandete beinlaget i bunnen 
av kammeret, som også fortsatte utenfor kammeret, kan representere begravelser tilknyttet mellomrøysa. I det omrota laget ble det identifisert bein fra flere individer (Denham 2009). Et høyt innslag av små kvartsavslag i beinlaget i bunnen av kammeret (Fig. 9) ses i relasjon til all kvartsen iblandet mellomrøysas to steinlag. Den store mengden kvartsbiter kan ses som et resultat av at knust kvarts har blitt kastet utover etter ferdigstillelse av anlegget.

Forekomster av kvarts er tidligere observert ved undersøkelser av gravminner, men gjerne uten at det gis en nærmere beskrivelse av karakter, omfang og kontekst. Et viktig unntak er utgravinga i Løgevik, Sokndal kommune lengst sør i Rogaland, der store mengder slått kvarts var spredt utover ei gravrøys (Juhl 1994). Kvartsbitene i kullaget i bunnen av kammeret på Håland minnet til forveksling om brente beinbiter, et trekk som tidligere er påpekt og diskutert (Lindgren 2008). En parallell fra Rogaland kan søkes i en gravhaug på Raunes i Vindafjord kommune der det ble observert innslag av kvarts i bunnen av gravgjemmet (Løken pers. meddelelse). Det vesle kammeret inneholdt brente bein og leirkarskår som kan dateres til perioden AD 300-500 (Løken 1982). I andre tilfeller forekommer kvartsen som større blokker synlige i anleggenes overflate (Shetelig 1912:121-149). Ved undersøkelse av gravfeltet Sylta i Uppland ble det påvist omfattende innslag av kvarts i to steinlegginger og tre kammergraver (Lindgren 2008). I hver av de fem gravene fra folkevandringstid var det 60-65 kilogram, noe som er svært interessant med tanke på at mengden kvarts i mellomrøysa på Håland ble veid til å være 66 kilogram. På bakgrunn av de kjente eksemplene som kan tidfestes, virker det som om kvarts særlig opptrer i gravkontekster fra yngre romertid og folkevandringstid. Beveger

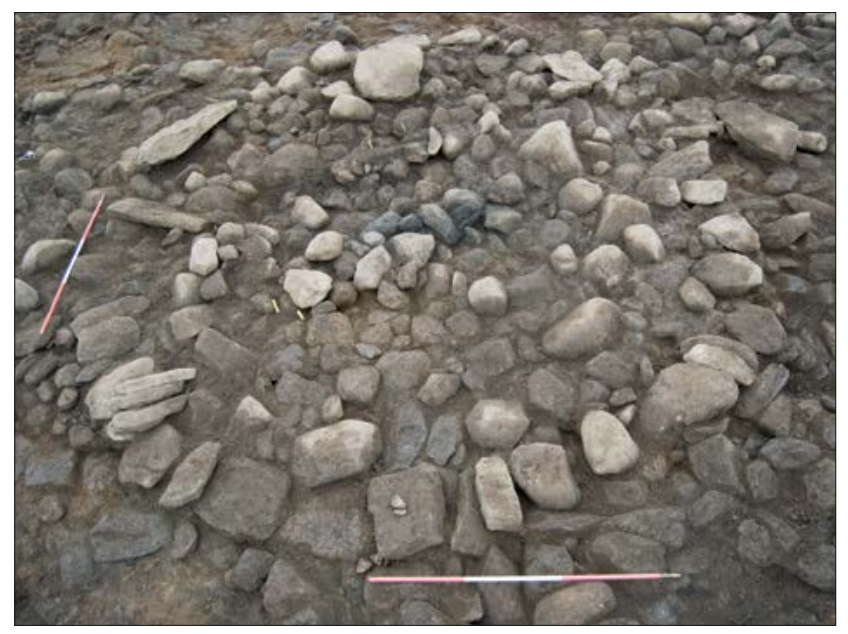

Fig. 7. Steinlegginga fra eldre førromersk jernalder. Foto: Arkeologisk museum, UiS.

Fig. 7. The kerb from Early Pre-Roman Age. Photo: Museum of Archaeology, University of Stavanger. vi oss over til de britiske øyer, der relasjonen mellom kvarts og graver er spesielt utbredt i nord og vest, er det imidlertid kjent eksempler fra hele tidsspennet yngre steinalder til tidlig kristne graver (Warren \& Neighbour 2004, Dennard 2005). Framfor en symbolsk betydning av kvartsen kan det tenkes at en nøkkel til forståelsen av relasjonen mellom graver og kvarts ligger i selve bearbeidelsen av materialet. Kvarts har egenskaper som gjør den lysende og elektrisk ladet ved mekanisk påvirkning. Den store mengden kvarts i mellomrøysa kan i likhet med det omfattende kullaget betraktes som bevarte spor etter døderitualer før, under og etter bygging av gravanlegget i yngre romertid. Kvartsen er slått fra større blokker og brakt til stedet, og det holdes som sannsynlig at bearbeidinga er relatert til den omfattende brenninga, før de hvite avslagene til slutt ble spredt utover det ferdigstilte anlegget som synlige spor og minner etter de ritualer de hadde vært en del av.

\section{Konstruksjon av kjernerøys med sorterte steinlag dekket av jordkappe og kammer med begravelser fra folkevandringstid}

Alle de eldre anleggene på stedet ble i overgangen mellom yngre romertid og folkevandringstid dekket av en monumental haug. Ei sirlig oppbygd kjernerøys av tre sorterte steinlag ble anlagt ut fra nøye plasserte sirkler av store steiner (Fig. 10, 11 og 12). Som yttermarkering på den sirkelrunde røysa ble det bygd et dobbelt bånd av små steiner. Det øvre laget i kjernerøysa framsto som et jevnt teppe av oppsiktsvekkende små steiner. Liknende tilfeller der enten runde eller flate småstein har dannet et toppdekke er tolket som utjevning av flata (Løken 1973, Randers 1988). Arbeidet må ha krevd nøye planlegging ved materialinnsamling og konstruksjon, noe som antyder bakenforliggende ideer ut over det rent funksjonelle og estetiske. Omstendigheten rundt og omtanken i bygginga av monumentet kan tas som indikasjon på religiøse motiver, som en insistering på en fastsatt orden i møtet med døden. Byggverket ble forseglet og skjult av tilskårne torvbrikker og påspadd jordmasse som dannet ei jordkappe med en diameter på 21 meter og 2,2 meters høyde på utgravingstidspunktet. Deltakerne i konstruksjonsprosessen satt således i ettertid kun igjen med minnet om det omstendelig oppbygde byggverket under jorddekket.

Begravelsene knyttet til kjernerøysa ble funnet i et stort tørrmurt kammer sentralt i anlegget. Ved undersøkelse av kammeret framsto gravgjemmet som skåret inn i den eksisterende mellomrøysa i forbindelse med konstruksjon av den større kjernerøysa. Kammeret var plassert direkte over eldre begravelser og inn i det eldre sammenblandede beinlaget som beskrevet tidligere. I tillegg til at det ble 
Fig. 8. Det øre laget av små steiner $\mathrm{i}$ mellomrøysa ses under storsteinslaget i kjernerøysa. Foto: Birdy Photographs. Fig. 8. The upper layer of smaller stones seen under the large stones in the bottom of the cairn above. Photo: Birdy Photographs.

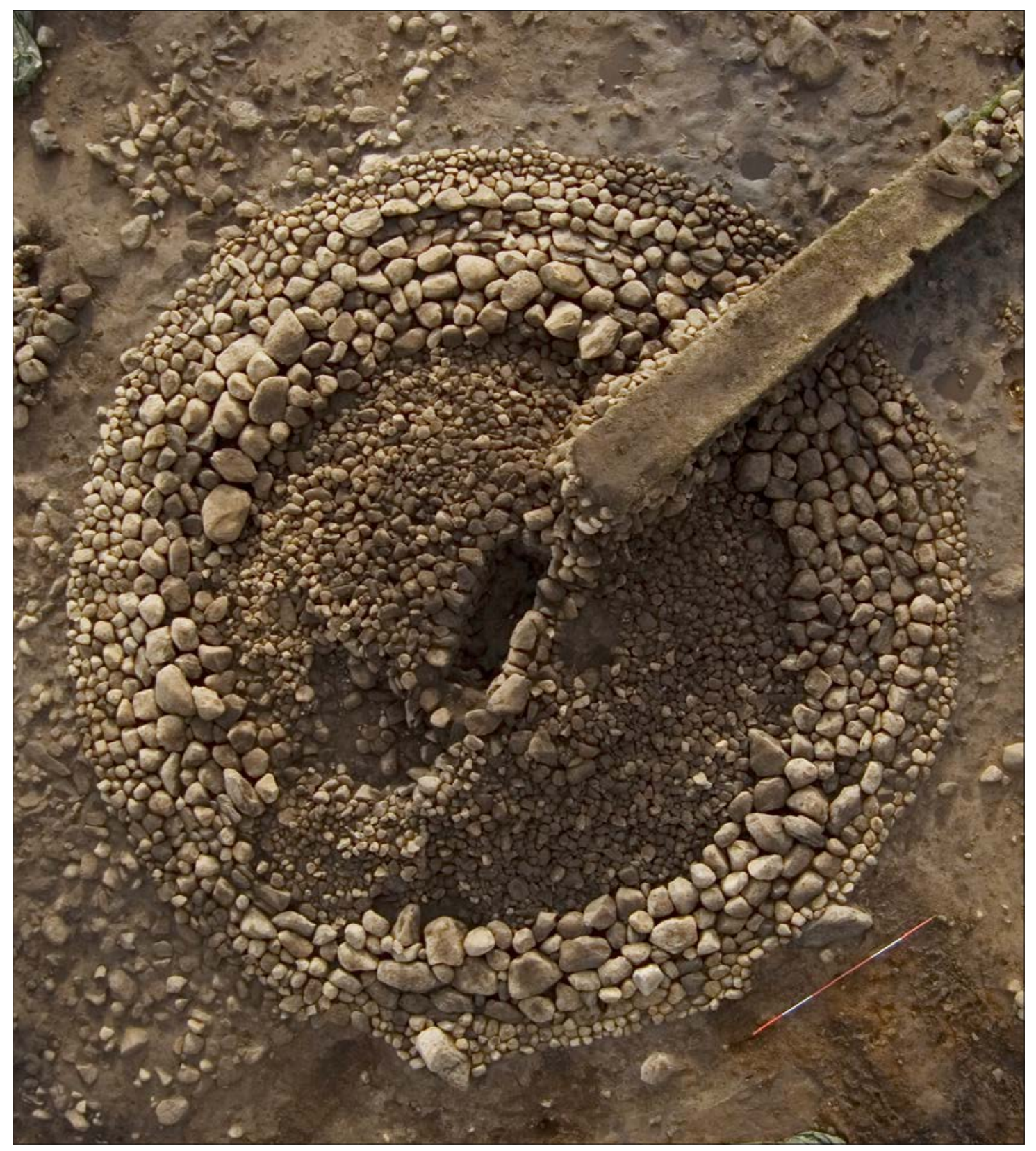

lagt vekt på å få en forståelse av hvordan kammeret relaterte seg til eldre kontekster, ble det fokusert på grundig dokumentasjon av kontekstene over kammeret for om mulig å få innsikt i seinere inngrep. Kammerets dekkheller var anlagt på tvers av lengderetningen, på en måte som muliggjorde enkel gjenåpning (jf. Shetelig 1912:101, 119). Både kontekstene over og inni kammeret gir klare holdepunkter for at det har funnet sted omroting og inngrep, sannsynligvis som ei rekke sekvenser over tid. Den opprinnelige skjelettgrava som kammeret antas å ha vært bygd for, framstår således som forstyrret i den grad at det ikke var mulig å finne bevarte spor etter den (jf. Shetelig 1912:101, Møllerop 1953). Mer oppsiktsvekkende framstår brenninga indikert ved de skjørbrente steinene på innsida av kammerets vegger. Brenninga har trolig blitt utført i forbindelse med gjenbruk av kammeret, en prosess som kan forklare hvorfor det ikke var bevarte spor etter den opprinnelige skjelettgrava. De osteologiske analysene viste at beina fra kammeret har vært utsatt for ulik brenningsgrad (Denham 2009, Fig. 13), noe som kan tolkes som at bein fra ulike kremeringsprosesser og begravelser er blandet sammen. De kremerte beina lå i en horisont mellom den eldste skjelettbegravelsen som kammeret antas å ha blitt bygget for og en skjelettbegravelse i toppen av kammeret. Situasjonen tilsvarer de tre begravelsessekvensene i Byrkjehaugens kammer (Shetelig 1912:101). Den yngste identifiserte begravelsen i kammeret i Hålandsmarka besto av en skjelettbegravelse med kniv og spyd med tange som kan tidfestes til siste del av folkevandringstid, rundt 550 e.Kr. (Shetelig 1912, 1917, 


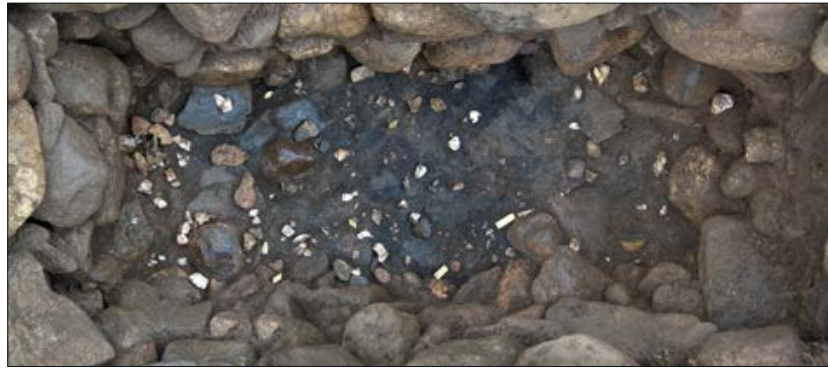

Fig. 9. Kvarts i bunnen av gravkammeret. Foto: Arkeologisk museum, UiS.

Fig. 9. Quartz in the bottom of the burial chamber. Photo: Museum of Archaeology, University of Stavanger.

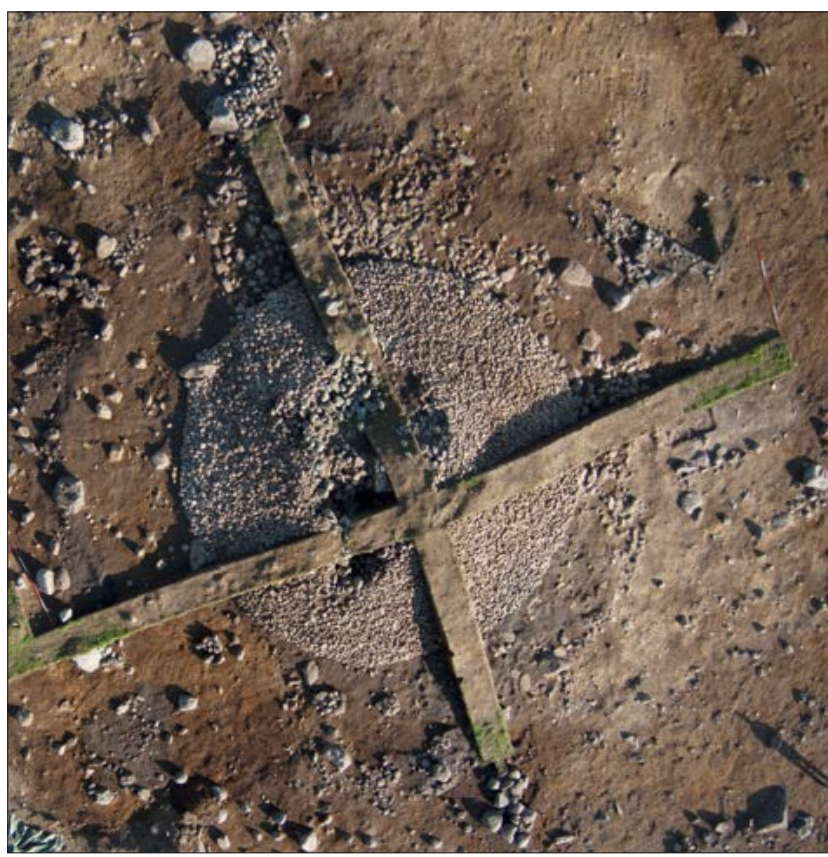

Fig. 10. Laget av småstein i toppen av kjernerøysa. Foto: Birdy Photographs.

Fig. 10. Layer of pebbles on top of the cairn. Photo: Birdy Photographs.

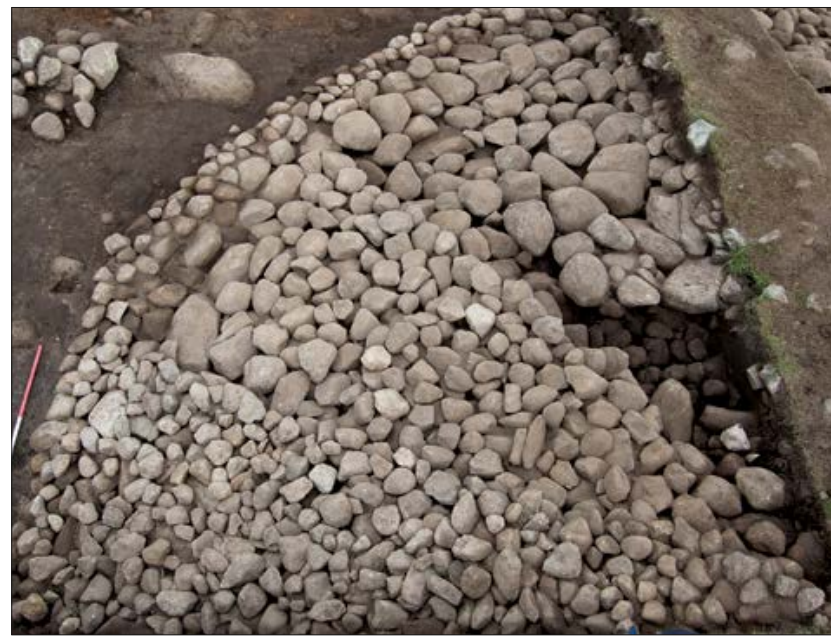

Fig. II. De tre sorterte steinlagene i kjernerøysa. Foto: Arkeologisk museum, UiS.

Fig. II. The three layers of sorted stones in the cairn. Photo: Museum of Archaeology, University of Stavanger.

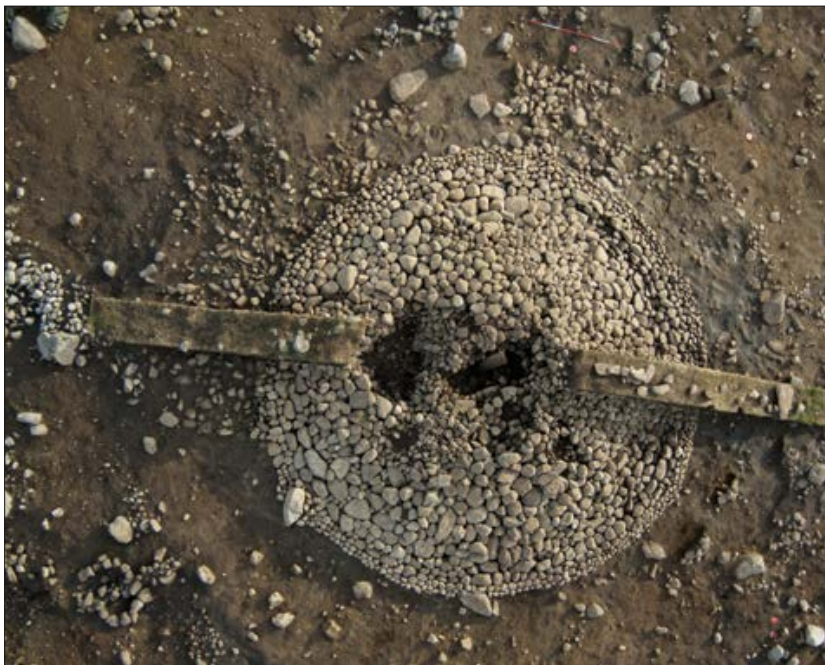

Fig. 12. Laget av store steiner i bunnen av kjernerøysa.

Yttermarkeringa består av et dobbelt kjede av små steiner med sirkler av store steiner innenfor. Foto: Birdy Photographs.

Fig. 12. The bottom layer of big stones in the cairn. Edge of cairn made of a double band of small stones with circles of big stones on the inside. Photo: Birdy Photographs.

Petersen 1926, Fett 1940, Solberg 1980, 1984, Bemmann \& Hahne 1994, Berge 2006). Det eldste diagnostiske funnet fra kammeret er en Niembergfibula som helst opptrer i eldste del av folkevandringstid (Shetelig 1910, Kristoffersen 2006). De diagnostiske funnene, sammen med brente bein med ulik brenningsgrad, indikerer således at kammeret har blitt benyttet til gjentatte begravelser gjennom hele folkevandringstid.

Siv Kristoffersen og Terje Østigård (2008) viser til flere lokaliteter hvor store kamre har vært gjenstand for flere begravelser i folkevandringstid. Haugene kunne bli benyttet som fellesgraver for en eller flere generasjoner, gjerne intensivt i en kort periode, slik at gravene kun kan skilles fra hverandre stratigrafisk. Både den enorme Byrkjehaugen på Voss i Hordaland og den monumentale haugen på Hove i Vik, Sogn og Fjordane viser klare fellestrekk med kammeret i haugen på Håland (Shetelig 1912:90-103, Næss 1996:138, Kristoffersen \& Østigård 2008:128). Tre ulike begravelsessekvenser ble identifisert i begge kamrene. I likhet med situasjonen i kammeret i Hålandsmarka var to inhumasjonsgraver atskilt av et mellomliggende kremasjonslag. I begge tilfellene var det mulig å identifisere flere individer blant de brente beinene i mellomsjiktet. I Byrkjehaugen og på Hove var det mulig å fastslå et relativt kort tidsspenn mellom de ulike begravelsessekvensene ut fra de spannforma skårene fra folkevandringstid (Kristoffersen \& Østigård 2008:130). Til tross for fravær av spannforma leirkarskår i kammeret i Hålandsmarka indikerer de andre diagnostiske funnene gjentatte begravelser gjennom hele folkevandringstid. 
Tabell I. Sammenstilling av ulike elementer fra forskjellige perioder i gravkompleks. Eksemplene er fra Rogaland, med unntak av Sakrishaugen som ligger i Hordaland. Table I. Comparison of elements from different periods in burial mounds. The examples are from Rogaland in SW Norway, with the exception of Sakrishaugen situated in Hordaland, W Norway.

\begin{tabular}{|c|c|c|c|c|c|}
\hline $\begin{array}{l}\text { Lokalitet/ } \\
\text { Site }\end{array}$ & $\begin{array}{l}\text { Perioder/ } \\
\text { Periods }\end{array}$ & $\begin{array}{l}\text { Steinlegging/ } \\
\text { Kerb }\end{array}$ & $\begin{array}{l}\text { Røys inni } \\
\text { kjernerøys/ } \\
\text { Cairn within cairn }\end{array}$ & $\begin{array}{l}\text { Innplassert kammer/ } \\
\text { Chamber built into } \\
\text { existing cairn }\end{array}$ & $\begin{array}{l}\text { Kullagl } \\
\text { Charcoal } \\
\text { layer }\end{array}$ \\
\hline $\begin{array}{l}\text { Mound I } \\
\text { Hålandsmarka }\end{array}$ & $\begin{array}{l}\text { E.BRA-MER/ } \\
\text { EBA-MerP }\end{array}$ & $\begin{array}{l}\text { FØRROM/ } \\
\text { PRIA }\end{array}$ & $\begin{array}{l}\text { Y.ROM/ } \\
\text { LRIA }\end{array}$ & $\begin{array}{l}\text { FVT } \\
\text { - over grav fra YROM } \\
\text { MP/ } \\
\text { - over burial from LRA }\end{array}$ & $\begin{array}{l}\text { Y.ROM/ } \\
\text { LRIA }\end{array}$ \\
\hline Salte & $\begin{array}{l}\text { E.ROM-FVT/ } \\
\text { ERIA-MP }\end{array}$ & & $\begin{array}{l}\text { E.ROM/ } \\
\text { ERIA }\end{array}$ & $\begin{array}{l}\text { FVT } \\
\text { - over grav fra FVT } \\
\text { MP/ } \\
\text { - over burial from MP }\end{array}$ & \\
\hline Sakrishaugen & $\begin{array}{l}\text { E.ROM-MER/ } \\
\text { RIA-MerP }\end{array}$ & $\begin{array}{l}\text { ROM/ } \\
\text { RIA }\end{array}$ & $\begin{array}{l}\text { ROM/ } \\
\text { RIA }\end{array}$ & $\begin{array}{l}\text { MER } \\
\text { - over grav fra } \\
\text { FVT MerPI } \\
\text { - over burial from MP }\end{array}$ & \\
\hline Ormshaug & $\begin{array}{l}\text { E.JA-Y.JA/ } \\
\text { EIA-LIA }\end{array}$ & & $\begin{array}{l}\text { E.JA/ } \\
\text { EIA }\end{array}$ & $\begin{array}{l}\text { FVT,Y.JA } \\
\text { MP, LIA }\end{array}$ & $\begin{array}{l}\text { E.JA/ } \\
\text { EIA }\end{array}$ \\
\hline Vigrestad & $\begin{array}{l}\text { Y.ROM-MER/ } \\
\text { LRIA-MerP }\end{array}$ & & & & \\
\hline Medhaug & $\begin{array}{l}\text { FØRROM-VIKI } \\
\text { PRIA-VA }\end{array}$ & & & & $\begin{array}{l}\text { FØRROM } \\
\text { IPRIA }\end{array}$ \\
\hline Foss-Eikeland & $\begin{array}{l}\text { FØRROM-Y.JAI } \\
\text { PRIA-LIA }\end{array}$ & & & & \\
\hline
\end{tabular}

\section{Parallelle kompleks med mange overlappende gravanlegg}

Komplekset i Hålandsmarka illustrerer en eksepsjonell lang og vedvarende bruk. For å understreke at haugen ikke bør betraktes som et isolert tilfelle, men tvert imot et eksempel på kompleksitet vi bør ta høyde for ved framtidige undersøkelser av gravminner, vil det kort presenteres noen liknende paralleller. Det er spesielt tre lokaliteter som kan bidra til å belyse ulike konstruksjonselementer og tolkninger av haugen i Hålandsmarka, samt tre andre undersøkelser som i korte trekk spilles inn mot slutten (se Tabell 1). De komplekse anleggene antyder at forvaltningsgravinger som kun siktes inn på å påvise én sentralt anlagt begravelse per haug, er å betrakte som et svært forenklet og foreldet syn på gravminner.

En første parallell er å finne i en haug (Fig. 14.) på Salte i Klepp kommune som rommet to kjernerøyser og hele 14 begravelser (Møllerop 1953). Den eldste røysa ble identifisert ved et tydelig kantkjede av større steiner. De to eldste kremasjonsgravene under røysa i bunnen kan tidfestes til eldre romertid. I tillegg til ei rekke graver plassert inn i selve røysa, ble det anlagt ei flatmarksgrav i nordlig ytterkant av kantkjedet.

I likhet med komplekset på Håland ble anlegget på Salte gjenstand for gjenbruk ved at det rundt år 500 ble innplassert et 4 meter langt gravkammer. Også her ble kammeret anlagt oppå et eldre brannflak, noe som viste seg ved at kullaget med brente bein og keramikk fortsatte under og utenfor kammeret. Brannflaket inneholdt to bronsefibler fra eldre romertid som viser likhet med fragmentet funnet i branngrava fra eldre romertid innplassert i steinlegginga i Hålandsmarka. I kammerets nedre lag ble det funnet brente bein og kull, men Møllerop antar at det store kammeret opprinnelig ble bygget for ei skjelettgrav selv om det ikke ble funnet bevarte ubrente bein. Den yngste kjernerøysa overskred den eldre røysa slik at kantkjedet ble liggende inne i den nye røysa. Flere av gravene kan knyttes til den yngste fasen da de lå utenfor romertidas steinkjerne. Odmund Møllerop fikk gjennomført osteologisk analyse av beinmaterialet der grav VIII og IIV viste det seg å være to barn (Møllerop 1953b:53ff, Lillehammer 2008:99).

En annen parallell med overlappende anlegg er å finne i Sakrishaugen, Voss kommune i Hordaland (Randers 1988, Kristoffersen \& Østigård 2008). Haugen med et bevart ytre mål på 19 meter rommet ei stor kjernerøys og minimum ei mindre røys lokalisert under sørlig del av den store kjernerøysa (Fig. 15 og 16). Sentralt i den yngste røysa var det oppbygd et mannslangt kammer med rester etter en forstyrret skjelettbegravelse. Spannforma leirkarskår med perledekor tidfester begravelsen til AD 550-600 (Randers 1988:12, Kristoffersen \& Østigård 2008:131-132). Kammeret viste seg også i dette tilfellet å være relatert til et eldre kremasjonslag. I konteksten ble det funnet brente bein og fragmenterte gjenstander, deriblant spannforma skår som antyder et kort tidsspenn mellom kremasjonslaget og kammeret. Den øverste kjernerøysa var dekket av ei jordkappe som besto av tre 


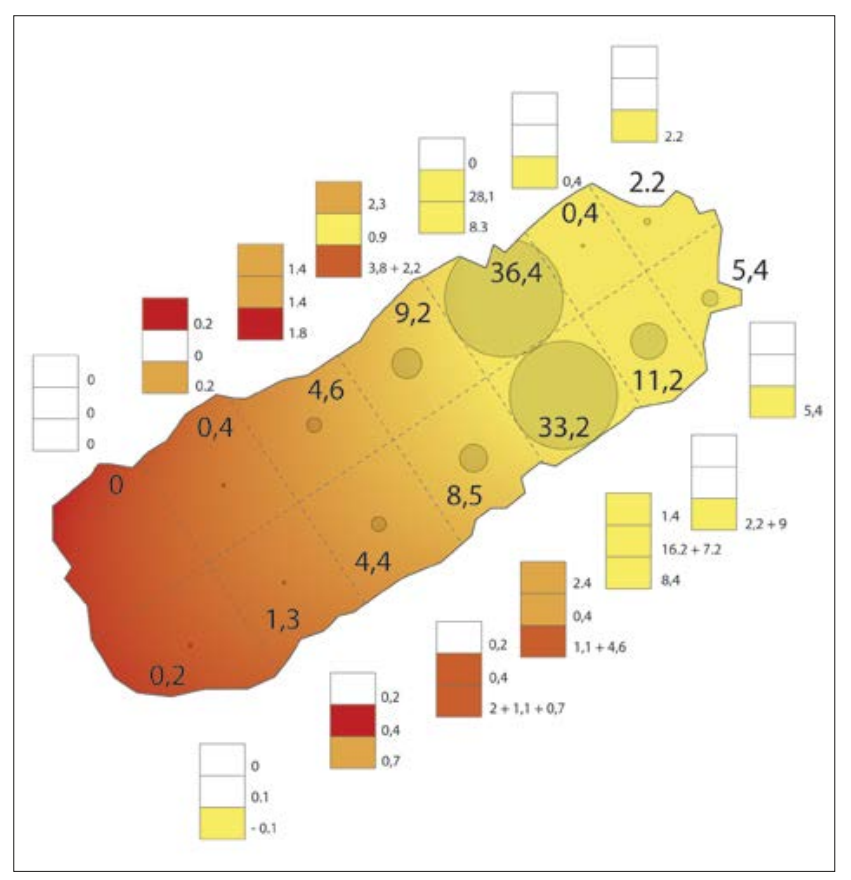

Fig. 13. Beinmaterialet framstilt etter brenningsgrad og mengdeforhold i ulike deler av kammeret. III. Theo Gil, basert på osteologisk analyse av Sean Denham.

Fig. 13. The bone material displayed after burning degree and amount in the different parts of the burial chamber. III. The Gil, based on the osteological analyses of Sean Denham.

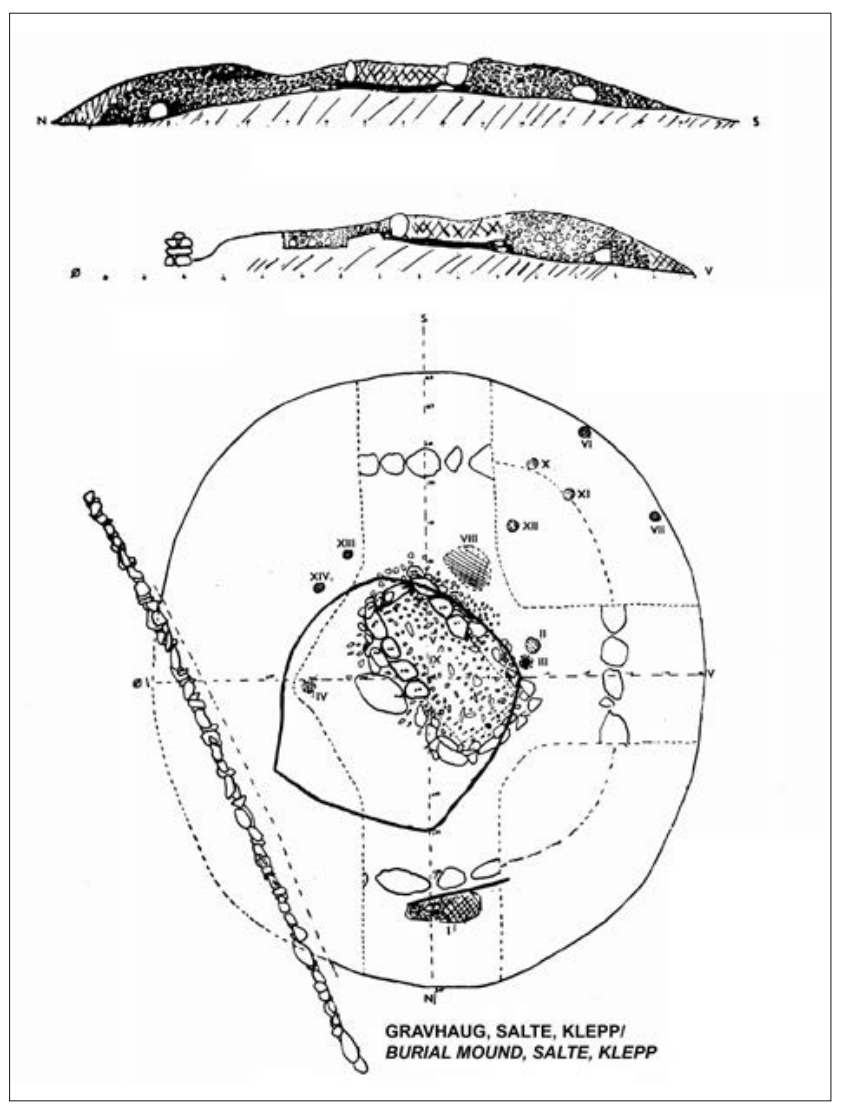

Fig. 14. Haugen på Salte i Klepp kommune, Rogaland (Modifisert etter Møllerop 1953).

Fig. 14. The mound at Salte, Klepp municipality, Rogaland (Modified after Møllerop 1953). ulike jordlag, vurdert til å representere ulike sekvenser i bygginga. Utgraver vurderte muligheten for at haugen kunne ha blitt tilført masse i forbindelse med gjenbruk av kammeret (Randers 1988:10). Den vesle røysa var dekket av et $20-40 \mathrm{~cm}$ tykt jordlag slik at vi må kunne gå ut ifra at også det eldre anlegget var forseglet av ei jordkappe (jf. betegnelsen lille gravhaug på Fig. 15).

Den mindre haugen som var lokalisert under sørlig del av den store kjernerøysa rommet en kremasjonsbegravelse fra perioden AD 100-300 (Randers 1988:14). Mot sørlig del av den vesle haugen ble det videre avdekket kull og brente bein som kan representere ei grav datert til overgangen mellom yngre romertid og folkevandringstid. Under et $20 \mathrm{~cm}$ tykt, noe humusholdig lag med innslag av spredte kullbiter, ble det påvist ei halvsirkelformet steinrekke som kan representere restene etter en eldre steinlegging med radius mellom de to haugene. Halvsirkelen viser store likheter med steinleggingas kantkjede på Håland og er en tydelig indikator på at det kan ha eksistert flere anlegg innenfor haugen. Ei kokegrop med datering til romertid lå under steinrekka, slik at det ser ut til å ha vært et høyt frekvensnivå i konstruksjon av anlegg og begravelser i tidsrommet AD 100-300.

Det tredje parallelle komplekset ble undersøkt i Sandnes kommune i 1967 og 1968 (Hafver 1968, Magnus Myhre 1968). Ved utgravinga av Ormshaug ble det identifisert fire steinlag atskilt av kull- og jordlag, sistnevnte tolket som mulige jordkapper over de to øverste røysene. Tre av fire steinlag var avgrenset av kantkjeder (Fig. 17). Den nederste røysa var bygd over et brannflak, og det ble også påvist brente bein, leirkarskår og skjørbrente steiner innenfor en indre steinkrets i den eldste røysa. Ved graving av den nest nederste røysa ble det funnet spredte, grove leirkarskår og en jernkniv, vidt tidfestet til eldre jernalder.

Et stort gravkammer tolkes som tilhørende den tredje røysa regnet fra bunn mot topp. Kammeret var ødelagt av en vanntank, men det ble funnet bevarte spor etter små heller tolket som kammerets bunn likt bunnen i kammeret i Hålandsmarka. Tidligere innleverte funn fra det ødelagte kammeret kan tidfestes til folkevandringstid og yngre jernalder (S1308-1312). Over den tredje røysas $20 \mathrm{~cm}$ tykke jordkappe var det lagt et øvre lag av store steiner. Hvis kammeret skal tolkes som tilhørende det tredje steinlaget, kan den yngste konstruksjonen være relatert til gjenbruken av kammeret. Det øvre steinlaget hadde imidlertid en mindre utstrekning enn den andre røysa, slik at denne fasens kantkjede stakk 1 meter utenfor kantmarkeringa i den øvre røysa. Den yngste røysa hadde et kantkjede av små steiner som, om enn noe mer 
Fig. 15. Sakrishaugen i Voss kommune, Hordaland (modifisert etter Randers 1988).

Fig. 15. The mound Sakrishaugen, Voss, Hordaland (modified after Randers 1988).

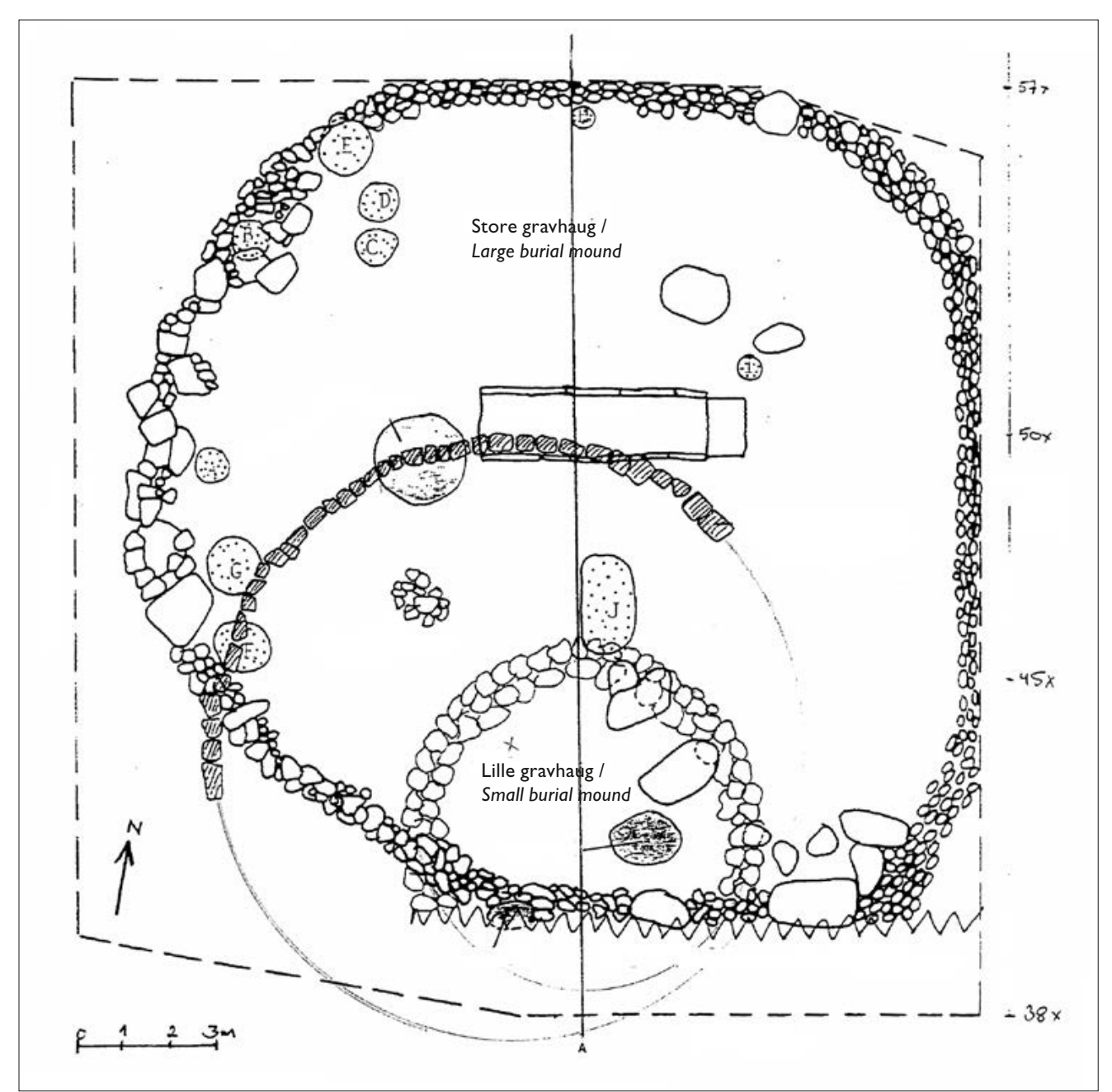

uregelmessig, viser likheter med det doble båndet av småstein rundt kjernerøysa i Hålandsmarka (jf. Fig. 17). Videre kan kullagene under og mellom de to eldste røysene i Ormshaug representere liknende kontekster som det omfattende kullaget under mellomrøysa fra yngre romertid på Håland. Et annet likhetstrekk kan sies å være en bemerkning om tilstedeværelse av kvarts under den første utgravingssesongen (Hafver 1968), dessverre uten at forekomsten beskrives nærmere eller knyttes til bestemte kontekster.

To forseglete torvlag dokumentert i monumentets jordkappe antyder seinere utvidelser av haugen på Håland, på tilsvarende måte som i Sakrishaugen (Randers 1988:10). Det holdes som sannsynlig at utvidelsene kan relateres til gjenbruk av kammeret. I forbindelse med nye begravelser kan omforming av det ytre monumentet ha spilt en viktig rituell rolle. I Rogaland er det kjent flere eksempler på at jordkappa har blitt påbygd ved nye begravelser. I en gravhaug på Vigrestad i Hå ble det identifisert sju ulike begravelser. Seks av gravene var anlagt i forskjellige nivå i anleggets sentrum, fra yngre romertid til merovingertid (Myhre 1965a). I Medhaug, på gården Espeland i Sandnes kommune, ble det identifisert tre begravelsessekvenser. Under haugen, direkte oppå undergrunnen, var det et stort 10-15 cm tykt kullag (Møllerop 1965a, 1965b). Et leirkar med brente bein og ei nål, som kan tidfestes til BC 400, var satt ned midt i kullaget. I et lite gravgjemme i haugens sørlige ytterkant ble det funnet ei urne med brente bein tidfestet til AD 400. I vikingtid ble det anlagt ei kremasjonsgrav i anleggets sentrum og haugen ble bygd 0,6 meter høyere (Thäte 2007:57 i katalogen).

Mens det i haugene på Vigrestad og Espeland ble påvist påbygging i form av ekstra jordmasser, finnes det andre eksempler på at gjenbegravelser i anleggets topp kan ha blitt dekket av et nytt steinlag. På Foss-Eikeland i Sandnes kommune ble det undersøkt en haug med ei urnegrav fra førromersk jernalder i bunnen, ei overliggende kremasjonsgrav fra AD 400 og ei båtgrav fra yngre jernalder i toppen (Hemdorff 1989). Over begravelsen fra folkevandringstid var det bygd på et ekstra steinlag, noe som er en klar parallell til det øverste steinlaget i Ormshaug i samme kommune.

Eksemplene illustrerer kompleksiteten som bør forventes ved utgravinger av gravhauger, både hva angår 


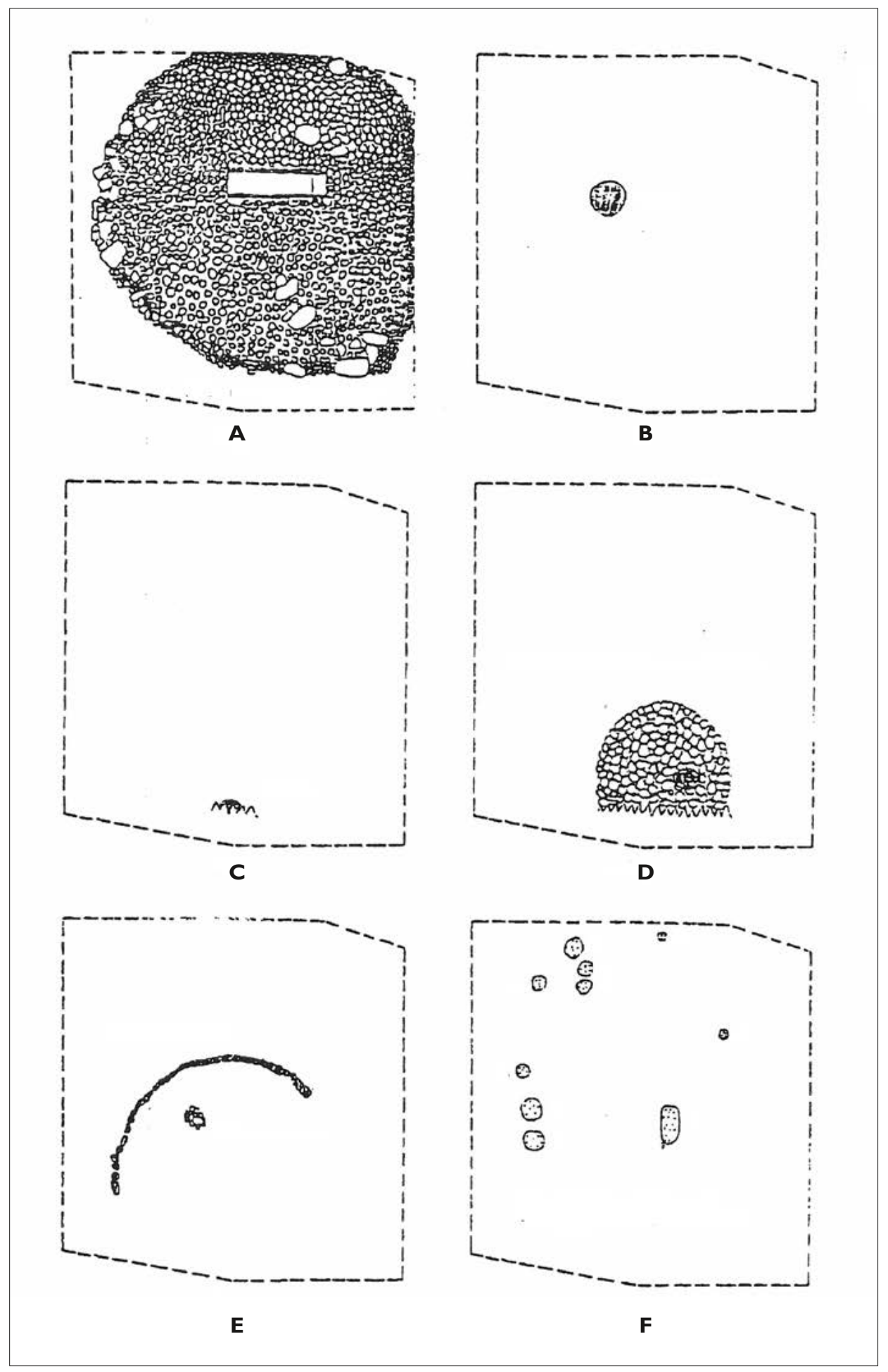

Fig. 16. Framstilling av de ulike fasene i Sakrishaugen, Voss, Hordaland (modifisert etter Randers 1988).

A) Røys m. kammer $600 \mathrm{AD}$,

B) Branngrav 550-600 AD,

C) Branngrav 400-500 AD

D) Branngrav, romertid,

E) Del av steinring, romertid,

F) Kokegroper og ildsteder, romertid og eldre.

Fig. 16. Display of different sequences in the mound Sakrishaugen, Voss, Hordaland (modified after Randers 1988).

A) Cairn with chamber $600 \mathrm{AD}$,

B) Cremation burial 550-600

$A D, C)$ Possible cremation burial 400-500 AD, D) Cremation burial, Roman Period, E) Part of stone circle, Roman Period, F) Cooking pits and fireplaces, Roman Period and older.

overlappende konstruksjoner, forekomst av omfattende kullag, gjenbegravelser og påbygginger. Til forskjell fra flere av eksemplene ovenfor ble det i Hålandsmarka imidlertid ikke påvist spor etter nye begravelser i haugen fra vikingtid. I vikingtid gravlegges tre døde individer 50 meter sør for den store gravhaugen, i tre lave røyser inntil og oppå to steinlegginger med begravelser fra yngre romertid. Til tross for at den monumentale haugen ble valgt bort som gravsted, er det indikasjoner på at komplekset øst på høydedraget fortsatt var gjenstand for ritualer som involverte konstruksjon av nye, varige spor knyttet til de hauglagte på stedet. Ved foten av jordkappa var det konstruert ei mindre røys av svært store steiner. Mjølbærfrø fra en prøve tatt under steinene har gitt datering til yngre vikingtid (TUa-8320). Mellom de store steinene i bunnen av røysa lå det en konsentrasjon av leirkarskår representative for lokalitetens varierte utvalg fra ulike faser. Således framstår funnene som omdeponerte 


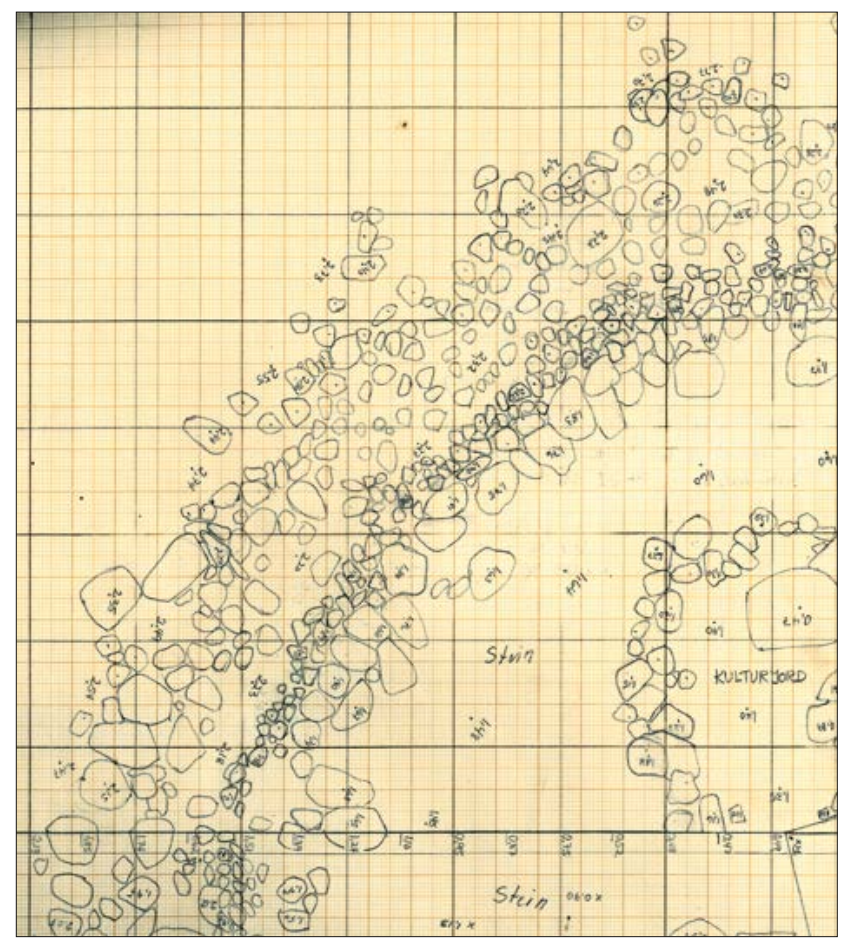

Fig. 17. Plantegning av kvadrant i Ormshaug, Sandnes kommune, Rogaland (Magnus Myhre 1968).

Fig. 17. Plan drawing of one of the quadrants in the mound

Ormshaug, Sandnes County, Rogaland (Magnus Myhre 1968).

fra ei rekke eldre kontekster på stedet. Levningene, trolig framkommet ved de seinere inngrepene som det var spor etter i monumentets sentrum, kan ha blitt inkorporert i nye ritualer for å påkalle de hauglagte og skape minneverdige, konkrete forbindelser til eldre begravelser (jf. Baudou 1989:34, Brendalsmo 1993, Artelius 2000, Williams 2006:118). Særs interessant i så måte er det at aktivitetene ikke er utført i tilknytning til vikingtidsbegravelsene, men til det store monumentet hvor ingen hadde blitt stedt til hvile siden slutten av folkevandringstid. Røysa anlagt i sein vikingtid kan betraktes som en påminner om at gravhauger kan ha utgjort viktige fokalpunkt for kommunikasjon også i perioder der det ikke blir påvist bevarte spor etter begravelser.

\section{Haugen som gravfelt gjennom to millennia}

"In summary, monuments can operate in relation to social memory in many complex ways, influencing and interacting with ritual actions, embodying cosmologies and origin myths, and acting as thresholds to other worlds, the resting places of ancestors or places of repeated engagement between the living and the dead" (Williams 2006:146).

Den vedvarende, overlappende bruken av gravplassen gir et inntrykk av kontinuitet som nettopp kan ha vært en nøye tilsiktet strategi der menneskene plasserte seg inn $\mathrm{i}$ ei tilsynelatende tidløs, mytisk fortid under kontinuerlig omforming (jf. Bradley 1987, Williams 2006). Fortida kan således betraktes som en ressurs i hendene på de levende (Bradley 1987:3).

Et interessant spørsmål vil være hva som avgjorde valget mellom bygging av nye anlegg kontra innplassering i eksisterende konstruksjoner. Det antas at selve byggeprosessen i enkelte perioder var tillagt avgjørende betydning i døderitualer som ble oppfattet som kritiske veiskiller i lokalmiljøets utvikling. Videre kan det påpekes en forskjell mellom innplassering av nye begravelser i eksisterende anlegg og plassering av nye begravelser som satellitter rundt og inntil eksisterende anlegg. Mens begravelsen i eldre romertid ble innplassert asentralt i steinlegginga, ble anleggene fra bronsealder anlagt utenfor den rektangulære haugen. På den andre sida kan begge fenomenene sies å ta hensyn til eldre gravanlegg, noe som står i kontrast til den omfattende utjevninga av den rektangulære haugen før bygging av steinlegginga i førromersk jernalder. En annen form for inkorporering av nye begravelser i eldre gravkontekster får vi i folkevandringstid ved de sammenblandede gravkontekstene i kammeret, som igjen er plassert over eldre begravelser på samme sted. De innplasserte kamrene på Salte og i Sakrishaugen var likeledes anlagt oppå eldre branngraver. De store gravkamrene peker både bakover i tid, til betydninga som ble tillagt tett kontakt med gravlagte forfedre, og framover i tid mot en bevissthet om at nye begravelser kontinuerlig kunne inkorporeres i eldre begravelser. Det vil imidlertid være vanskelig å avgjøre om kamrene intensjonelt ble konstruert med tanke på lang tids bruk, eller om den vedvarende bruken kun var et resultat av ettertidas behov for en tett sammenveving med de hauglagte.

Hvis vi ser hele gravfeltet i Hålandsmarka under ett, men også den monumentale haugen spesielt, er gravene fra eldre jernalder utrustet med keramikk og personlig utstyr festet til kropp eller bekledning slik som ei enkelt draktspenne. Gjenstandene lagt ned i begravelsen i toppen av kammeret fra slutten av folkevandringstid illustrerer også endringene i gravutrustinga mellom eldre og yngre jernalder i Hålandsmarka. Gjenstandene kan betraktes som en del av bekledninga, men nå i et større utvalg i form av kniv, spyd, spenner og ildslagningsflint. Kildekritisk sett må det samtidig påpekes at mønsteret i gravutrustinga følger samme skille som det mellom kremasjon og inhumasjon. Det store kammeret illustrerer en overgangsperiode preget av vekslende kremasjon og inhumasjon. Kammeret antas å ha blitt bygd for å romme ei skjelettgrav, men er blitt kraftig skadet ved anleggelse av minst én ny kremasjonsbegravelse og én ny 
skjelettbegravelse. Gravgjemmet representerer et spennende innblikk i skiftende likbehandling fra inngangen til utgangen av folkevandringstid.

Dateringa av kullaget under haugen faller innenfor samme periode som det ble konstruert gravanlegg både øst og sør på høydedraget, spor som gir inntrykk av et høyt aktivitetsnivå i henhold til bruk av området som gravsted i yngre romertid. Det er fristende å se dette i sammenheng med økningen av bosettingsspor i regionen, noe som gir et klart inntrykk av befolkningsvekst og indre landnåm i yngre romertid og folkevandringstid. Sistnevnte periode er i vårt materiale farget av en omfattende gjenbruk av det store kammeret i haugen. Gjenbruken kan ses som et konkret uttrykk for at den monumentale haugen spilte en sentral rolle i lokalsamfunnets historieframstilling gjennom hele folkevandringstid (jf. Artelius 2000:17). Selve konstruksjonen av det sirlige byggverket kan med stor sannsynlighet tilskrives samme periode, og jordkappa ble videre trolig utvidet ved gjenbruk av kammeret ut gjennom folkevandringstid. Påvisning av rug i jordkappas øvre lag kan muligens tas som indikasjon på tilført masse også etter folkevandringstid da rug blir mer vanlig i yngre jernalder (Børsheim \& Soltvedt 2002:165).

Bygginga av det imponerende anlegget må ha krevd nøye planlegging og mobilisering, ikke bare i forhold til selve konstruksjonsarbeidet, men også til innsamling av de ulike materialene benyttet i sorterte sekvenser. De ulike byggematerialenes opphav kan ha hatt en viktig symboleffekt som en sammenbinding av elementer fra nøye utvalgte steder. De utskårne torvene kan tenkes å representere fruktbar mark, mens kvartsen enten må være oppsamlet over store områder eller i sin helhet hentet fra et kjent brudd. De ulike elementene kan ha hatt en spesiell betydning ved å ha inngått i eldre, betydningsfulle kontekster, slik tilfellet antas å være for det varierte utvalget av keramikk fra ulike tidsperioder i den vesle røysa vest for haugen. Samtidig kan byggematerialene representere steder viktige i fortellinga om avdødes liv, bevegelser og territorium.

Planlegging og gjennomføring av byggverket kan ha bidratt til å visualisere, befeste eller utfordre systemer av hierarki. Vi må kunne gå ut fra at døden involverte hele lokalsamfunnet, og i det påfølgende dramaets muligheter for kontinuitet og endring lå krafta i døderitualene, bygging av monumenter og monumentenes videre mytologisering i landskapet. Begravelsesritualene inkluderte både en dialog med høyere makter, forfedre og samfunnet generelt (Gansum \& Østigård 2004).

Komplekset av overlappende gravminner kan betraktes som en scene, og begravelsesprosessen kan beskrives som et rituelt teater (jf. Williams 2006:26, 135). Handlingene fundamenteres i fortid, utspilles i nåtid med ambisjoner for framtida. Begravelse og gravplass muliggjorde sammenkopling mellom fortida og de døde med det levende samfunn. Prosessen medførte at de avdøde fikk ny identitet som forfedre, samtidig som deltakelse i begravelsesritualene ga personlige, kroppslige erfaringer. Ønsket om å skape nye minneverdige erfaringer for deltakerne kan videre bidra til å rette søkelys mot hvordan variasjon og endring kan påtreffes innenfor relativt korte tidsrom, noe som kan danne et interessant bakteppe for forståelsen av de ulike begravelsene i haugens kammer, nye konstruksjoner og påbygginger. Gjennom deres materialitet kan monumenter tilskrive steder minner, omforme dem og inkorporere minnene i deltakernes kroppslige erfaring.

\section{Takk}

En stor takk rettes til et fabelaktig feltmannskap i Hålandsmarka: Hilde Frydenberg, Theo Gil, Synnøve Thingnæs, Solveig Roti Dahl, Sean Denham, Krister Eilertsen, Silje Foyn, Therese Jåtten, Erlend Nordli, Nora Pape og konservator Nathalie Hanna. En spesiell takk til Theo Gil for illustrasjoner og Sean Denham for engelsk korrektur av abstract og summary. Tusen takk til forskningsrådet ved Arkeologisk museum for å ha bevilget to uker til skriving av denne artikkelen om Hålandsmarka, og takk til referee for fruktbare innspill.

\section{Summary}

The burial mound at Hålandsmarka is presented as an example of the complexity that might be expected when excavating grave monuments. One must view burial mounds in a long-term perspective, as representing ongoing cultural processes rather than a single burial event. In order to fully understand these processes, it is necessary to investigate not only the burial mound, but the surrounding areas, where there may be satellite structures and features of relevance. Rather than simply the excavation of a burial mound, the project at Hålandsmarka may best be described as the reconstruction of two thousand years of activity through the deconstruction of an entire landscape into discrete sequences. In this way, a monumental mound can be very important for new knowledge about the development of and changes in local burial customs over long periods of time.

The identification of burials that can be dated to various periods within older burial mounds is clear evidence of the continuous use and social relevance of these monuments. Other traces of use must also be considered, as at Hålandsmarka with its massive charcoal layer, its 66 kilograms of quartz fragments spread out over the cairn, its evidence of partial destruction for the construction of new monuments, and the building of satellite cairns without preserved burial evidence. It is suggested that Hålandsmarka should not be seen as an isolated case. Several of the sequences identified within the mound are also present 
in other excavated burial mounds in southwest Norway, often from the same periods (see Table 1). This is especially the case with the continuous use of centrally placed grave chambers throughout the Migration Period.

This presentation focuses on the flexibility between building new visible burial structures and incorporating new burials into existing structures. It is believed that part of the explanation can be sought in the construction process itself and the role that it may have played in a society facing death. At times of intensive use, the impression is one of large numbers of people being involved in the burial activities. In Hålandsmarka, the collective aspect is perhaps best seen in the Late Roman Iron Age and Migration Period with a massive charcoal layer covered by two cairns, the youngest constructed of carefully sorted stone layers, sealed by massive layers of cut peat. While one can imagine a large number of people being involved in these activities, it cannot be ruled out that the construction process was directed by a narrow group of people. The tediously sorted stones layered in almost perfect circles indicate a highly organised operation, probably directed by some individuals with special knowledge and a key role in conducting the rituals. The rituals can be seen as important opportunities for reaffirming group identity through communal activity as well as influencing the future distribution of power.

\section{Referanser}

Almgren, O. 1897. Studien über nordeuropäische Fibelformen der ersten nachchristlichen Jahrhunderte. Dr.art.-avhandling, Uppsala. Drück von Ivar Hæggström, Stockholm.

Amundsen, J. 2008. Fosfatanalyse røysstrukturer Hålandsmarka, Håland gnr. 4, bnr. 1, Time kommune. Upublisert rapport, Arkeologisk museum, UiS.

Anglert, M., Artursson, M. \& Svanberg, F. (red.) 2006. Kulthus $\mathcal{E}$ dödshus. Det ritualiserade rummets teori och praktik. Riksantikvarieämbetet, Stockholm.

Artelius, T. 2000. Bortglömda föreställningar. Begravningsritual och begravningsplats $i$ halländsk yngre järnålder. Riksantikvarieämbetet, Arkeologiska Undersökningar, Skrifter 36 Gotarc. Series B. Gothenburg Archaeological Theses 15.

Barclay, G.J. 1984. Innberetning fra Helgøy, Finnøy kommune. Topografisk arkiv, Arkeologisk museum, UiS.

Baudou, E. 1989. Hög - gård - helgedom. Mellomnorrland under den äldre järnålder. Arkeologi i Norr 2, 9-43.

Bemmann, J. \& Hahne, G. 1994. Waffenführende Grabinventare der jüngeren römischen Kaiserzeit und Völkerwanderungszeit in Skandinavien. Studie zur zeitlichen Ordnung anhand der norwegischen Funde. Bericht der Römisch-Germanischen Kommission Band 75, 293-558.

Berge, J. 2006. Våpen og stridsteknikk i overgangen mellom eldre og yngre jernalder. Upublisert hovedfagsoppgave i arkeologi, Universitetet i Bergen.

Bradley, R. 1987. Time regained: the creation of continuity. Journal of the British Archaeological Association Vol. 140, 1-17.

Brendalsmo, A.J. 1993. De døde lever... Spor 1, 2-15.
Brown III, M.R. \& Harris, E.C. 1993. Interfaces in archaeological stratigraphy. I Harris, E.C., Brown III, M.R. \& Brown, G.S. (red.). Practices of Archaeological Stratigraphy, 1-20.

Børsheim, R.L. \& Soltvedt, E.-C. 2002. Gausel-utgravingene 1997-2000. AmS-Varia 39, Arkeologisk museum, UiS.

Dahl, B.I. 2009. Gravene i Hålandsmarka på Bryne. Frá haug ok heidni 1, 3-8.

Dahl, B.I. 2014. Arkeologisk utgraving av hus og graver. Myklebust gnr. 3, Sola kommune, Rogaland. Oppdragsrapport 2014/20, Arkeologisk museum, UiS.

Dahl, B.I., Lillehammer, G. \& Hemdorff, O.H. 2008. Prosjektplan for arkeologisk utgravning $i$ Hålandsmarka, Håland gnr. 4, bnr. 1, Time kommune. Arkeologisk museum, UiS.

Denham, S.D. 2009. Analysis of cremated bone from Hålandsmarka, Time. Upublisert rapport, Arkeologisk museum, Universitetet i Stavanger.

Dennard, C. 2005. All that glitters is not gold: An analysis of the occurrence of quartz at Neolithic and Bronze Age ritual monuments. Unpublished Masters dissertation, University of Edinburgh.

Dommasnes, L.H. 2001.Tradisjon og handling $i$ førkristen vestnorsk gravskikk. II. Fra Vereide til vikingtid. Arkeologiske avhandlinger og rapporter fra Universitetet i Bergen 5.

Farbregd, O. 1980. Perspektiv på Namdalens jernalder. Undersøkingar på Veiem, Sem, Værem og Bertnem. Viking XLIII, 20-80.

Fett, P. 1940. Arms in Norway between 400 and 600 A.D. Part I. Bergens Museums Arbok 1938, 5-89.

Frydenberg, H.S. 2009. Arkeologisk utgraving av røyser på lokalitet Hålandsmarka gnr. 4, bnr. 1, Time k. Oppdragsrapport B 2009/08. Universitetet i Stavanger/ Arkeologisk museum.

Gansum, T. 2004. Hauger som konstruksjoner arkeologiske forventninger gjennom 200 år. Gotars Serie B. Gothenburg Archaeological Theses No 33.

Gansum, T. \& Østigaard, T. 2004. The ritual stratigraphy of monuments that matter. European Journal of Archaeology Vol. 7 No. 1, 61-79.

Gil, T. B. 2009. Arkeologisk utgraving av gravhaug på lokalitet Hålandsmarka gnr. 4, bnr. 1, Time $k$. Oppdragsrapport B 2009/10. Universitetet i Stavanger/ Arkeologisk museum.

Glørstad, Z. \& Wenn, C.C. 2013. En gambler langs veien. Nytt blikk på grav og gravritualer i eldre jernalder. Viking LXXVI, 113-136.

Hafver, J. 1968. Innberetning om utgravning av en gravhaug „Ormshaug" på Årsvoll, gnr. 64, bnr. 18, Høyland. Topografisk arkiv, Arkeologisk museum, UiS.

Haraldsen, T. 1978. Innberetning fra utgraving av gravrøys/boplass 1978, Førre 79/10, Tysvar kommune. Topografisk arkiv, Arkeologisk museum, UiS.

Harris, E.C. 1979. Principles of Archaeological Stratigraphy. Academic Press.

Hemdorff, O.H. 1989. Innberetning om undersøkelse av fornminne 2186 I2 R2, Foss-Eikeland gnr. 50, bnr. 4, Sandnes kommune. Topografisk arkiv, Arkeologisk museum, UiS. 
Høgestøl, M. 1995. Arkeologiske undersøkelser i Rennesøy kommune, Rogaland, Sørvest-Norge. AmS-Varia 23, Arkeologisk museum, UiS.

Juhl, K. 1994. Innberetning til topografisk arkiv, Løgevik gnr. 81, bnr. 1, Sokndal kommune. Topografisk arkiv, Arkeologisk museum, UiS.

Kristoffersen, S. 2006. Kvinnedrakten fra Rogaland $i$ folkevandringstid. Draktutstyr. AmS-Varia 45.

Kristoffersen, S. \& Østigaard, T. 2008. "Death Myths": Performing of Rituals and Variation in Corpse Treatment during the Migration Period in Norway. I Fahlander, F. \& Oestigard, T. (red.). The Materiality of Death. Bodies, Burials, Beliefs. BAR International Series 1768/2008, 127-140.

Lillehammer, G. 2008. Transforming Images: Exploring Powerful Children. Childhood in the Past Vol. 1, 94-105.

Lindgren, C. 2008. Stones and Bones: The Myth of Ymer and Mortuary Practices with an Example from the Migration Period in Uppland, Central Sweden. I Fahlander, F. \& Oestigard, T. (red.). The Materiality of Death. Bodies, Burials, Beliefs. BAR International Series 1768, 155-160.

Løken, T. 1973. Utgravning av gravrøyser på Gullvikav Rømmen, Bjugn, Sør-

Trøndelag. Rapport, Arkeologisk serie 1973 - 1, Det Kongelige Norske

Videnskabers Selskab, Vitenskapsmuseet.

Løken, T. 1974. Gravminner i Østfold og Vestfold. Et forsøk på en typologisk-kronologisk analyse og en religionshistorisk tolkning. Del 1: Tekst. Avhandling til magistergraden i Nordisk arkeologi ved Universitetet i Oslo.

Løken, T. 1982. Jernalder og oljealder på Raunes. Frá haug ok heidni 3, 64-68.

McLess, C., Nordeide, S.W., Petersén, A. \& Saunders, T.1994. The production of archaeological knowledge: The theory and method of urban excavation. Meta 2, 3-29.

Myhre, B. 1965a. Innberetning om utgravning av haug 3 på Vigrestad gnr. 77, bnr. 4, Hå k. Topografisk arkiv, Arkeologisk museum, UiS.

Myhre, B. 1965b. Et keltertids gravfunn fra Espeland i Høyland. Frá haug ok heiđni

3, 132-136.

Myhre, B. 2007. Lye i Time på Jæren i Sørvest-Norge - et glemt sentralsted fra eldre jernalder. Publisert på http://jenny-rita.org/bjomyh.html

Myhre, B.M. 1968. Innberetning om utgravningen av „Ormshaug“, Årsvoll, gnr. 64 bnr. 18, Høyland. Topografisk arkiv, Arkeologisk museum, UiS.

Møllerop, O. 1953a. Innberetning til topografisk arkiv, Salte i Klepp. Topografisk arkiv, Arkeologisk museum, UiS.

Møllerop, O. 1953b. En gravhaug på Salte i Klepp. Stavanger Museums Årbok,

40-63.

Møllerop, O. 1965. Haug 3 på Vigrestad. Frá haug ok heiđni 3, 143-144.

Næss, J-R. 1969. Arkeologenes feltsesong 1969 i Rogaland. Frá haug ok heiđni 3 og 4, 255-280.

Næss, J.-R. 1996. Undersøkelser $i$ jernalderens gravskikk på Voss. AmS-Rapport 7, Stavanger.
Petersen, J. 1924. Undersøkelse av gravhaug på Strand $i$ Strand. Topografisk arkiv, Arkeologisk museum, UiS.

Petersen, T. 1926. Videnskapsselskapets Museum. Tilvekst av Oldsaker 1926. Det kongelige norske videnskabers selskabs skrifter No. 3, 1-62.

Randers, K. 1988. Sakrishaugen på Voss. Lydvo, gnr. 37/1, Voss kommune, Hordaland. Rapport fra utgraving. Topografisk arkiv, Historisk Museum, Universitetet i Bergen.

Shetelig, H. 1910. Smaa broncespæender fra folkevandringstiden. Separatavtryk av Oldtiden for 1910.

Shetelig, H. 1912. Vestlandske graver fra jernalderen. Bergens Museums Skrifter. Ny række. Bd. II No. 1.

Shetelig, H. 1917. Nye jernaldersfund paa Vestlandet. Bergens Museums Aarbok 1916-17. Hist.-antikv. række, 7-86.

Skjelsvik, E. 1953. Steinsetninger og steinlegninger i Norge. Et bidrag til deres datering og forståelse. Hovedoppgave i nordisk arkeologi, Universitetet i Oslo.

Solberg, B. 1980. Spearheads in the transition period between the early and the late Iron Age in Norway. Acta Archaeologica vol. 51, 153-172.

Solberg, B. 1984. Norwegian spear-heads from the Merovingian and Viking periods. Dr.art.-avhandling, Universitetet i Bergen.

Solberg, B. 2000. Jernalderen i Norge. 500 før Kristus til 1030 etter Kristus. Cappelen akademisk forlag.

Svanberg, F. 2006. I de mystiska kulthusens mörka inre. I Anglert, M., Artursson, M. \& Svanberg, F. (red.). Kulthus $\mathcal{E}$ dödshus. Det ritualiserade rummets teori och praktik, 123-128. Riksantikvarieämbetet, Stockholm.

Thäte, E.S. 2007. Monuments and Minds. Monument Re-use in Scandinavia in the Second Half of the First Millennium AD. Acta Archeologica Lundensia Series in $4^{\circ}$ No. 27.

Thingnæs, S. 2009. Arkeologisk utgraving av gravrøys og flateavdekking på lokalitet Hålandsmarka gnr. 4, bnr. 1, Time k. Oppdragsrapport B 2009/09. Universitetet i Stavanger/Arkeologisk museum.

Victor, H. 2006. Bronsålderns kulthus - ett dateringsproblem i en komplex miljö. I Anglert, M., Artursson, M. \& Svanberg, F. (red.). Kulthus \& Dödshus. Det ritualiserade rummets teori och praktikk, 113-122. Riksantikvarieämbetet, Stockholm.

Wangen, V. 1998. Gravfeltet på Gunnarstorp. II. Katalog. Avhandling til magistergrad i nordisk arkeologi, IAKN, Det historisk-filosofiske fakultet, Universitetet i Oslo.

Wangen, V. 1999. Gravfeltet på Gunnarstorp. I Et monument over dødsriter og kultutøvelse. Avhandling til magistergrad i nordisk arkeologi IAKN, Det historisk-filosofiske fakultet, Universitetet i Oslo.

Wangen, V. 2009. Gravfeltet på Gunnarstorp i Sarpsborg, Østfold: et monument over dødsriter og kultutøvelse $i$ yngre bronsealder og eldste jernalder. Norske Oldfunn 27, Kulturhistorisk museum, $\mathrm{UiO}$.

Warren, G. \& Neighbour, T. 2004. Quality Quartz: Working stone at a Bronze Age Kerbed Cairn at Olcote, near Calanais, Isle of Lewis. Norwegian Archaeological Review Vol. 37, 83-94. 
Williams, H. 2006. Death and Memory in Early Medieval Britain. Cambridge Studies in Archaeology. Cambridge University Press.

Østmo, E. \& Hedeager, L. (red.) 2005. Norsk arkeologisk leksikon. 